RADOVI

Zavoda za znanstveni rad HAZU Varaždin

VILENA VRBANIĆ

Zagreb

vilena.vrbanic@gmail.com
UDK 681.816:069(497.523Varaždin) Izvorni znanstveni članak Original Scientific Paper

Primljeno: 17. 01. 2018.

Prihvaćeno: 11. 04. 2018.

DOI: https://dx.doi.org/10.21857/y26kec36o9

\title{
INSTRUMENTI S TIPKAMA IZ FUNDUSA GRADSKOG MUZEJA VARAŽDIN ${ }^{1}$
}

Rad donosi rezultate istraživanja instrumenata s tipkama iz fundusa Gradskog muzeja Varaždin (GMV). Zastupljeno ih je ukupno 12: deset klavira - stolni klavir, pet povijesnih klavira iz proe polovice 19. stoljeća, četiri klavira iz druge polovice 19. stoljeća - te dva pozitiva iz 17. stoljeća. Budući se radi o relationo nepoznatom području, rad se bavi problemima koji do sada nisu bili sustavno obradivani. U vrijeme kada su se rabili, instrumenti koji se čuvaju u GMV-u bili su među glavnim preduvjetima muziciranja u Varaždinu i varaždinskoj okolici. Sa stajališta muzikologije može ih se smatrati jednim od ključnih elemenata u proučavanju glazbene kulture ovog područja. Istraživanjem se otkrivaju detalji vezani uz njihov razvojni put, zakoni gradnje, kao i materijalne prilike i glazbeni ukus njihovih prijašnjih vlasnika. Neke od njih upravo je pohrana u GMV spasila od nestajanja, a nekima je omogućila i prijeko potrebnu restauraciju kojom im je vraćen stari sjaj i mogućnost da se na njima ponovno muzicira.

1 Ovaj je članak dio poglavlja „Glazbeni instrumenti iz fundusa Gradskog muzeja Varaždin” doktorske disertacije u izradi, koja nosi naslov Glazbeni instrumenti umjetničke glazbe u hrvatskim muzejima. Autorica ga izrađuje na poslijediplomskom doktorskom studiju hrvatske kulture na Filozofskom fakultetu Sveučilišta u Zagrebu pod mentorstvom dr. sc. Vjere Katalinić, nasl. red. prof. 


\section{O GRADSKOM MUZEJU VARAŽDIN}

Kao javna ustanova u kulturi, Gradski muzej Varaždin (dalje GVM) čuva, prikuplja i predstavlja duhovnu i materijalnu baštinu varaždinskoga područja. Utemeljen je na poticaj Varaždinskoga muzealnog društva i svečano otvoren za posjetitelje 16. studenog 1925. godine, u prostoru utvrde Stari grad. Jezgru prvotnog postava sačinjavali su predmeti prispjeli u novootvoreni Muzej ponajviše kao donacije poznatih varaždinskih obitelji. Tijekom godina obogaćivale su se zbirke zahvaljujući kojima je Muzej prerastao u ustanovu kompleksnoga tipa, sastavljenu od sedam specijaliziranih odjela: Arheološkog, Povijesnog, Kulturnopovijesnog, Etnografskog, Entomološkog, Galerije starih i novih majstora te Konzervatorsko-restauratorskog. Muzejski odjeli danas su smješteni u nekoliko građevina spomeničke vrijednosti, u samoj povijesnoj jezgri Varaždina: gotičkorenesansnoj utvrdi Stari grad, baroknoj palači Sermage, klasicističkoj palači Herzer te Kuli stražarnici u kompleksu Staroga grada. U sklopu muzejskih odjela uređena su tri stalna muzejska postava: Kulturnopovijesnoga odjela u Starome gradu, Entomološkoga odjela u palači Herzer te Galerije starih i novih majstora u palači Sermage. ${ }^{2}$ Glazbeni instrumenti čuvaju se u Glazbenoj zbirci Kulturnopovijesnog odjela. Uz to, još četiri instrumenta zastupljena su u Etnografskom odjelu: u Zbirci običaja pohranjena je jedna citra (dječja), a u Zbirci predmeta tradicijskog domaćinstva tri cimbala. ${ }^{3}$

\section{O GLAZBENOJ ZBIRCI GRADSKOG MUZEJA VARAŽDIN}

Od glazbenih instrumenata u Glazbenoj zbirci GMV-a čuva se deset klavira, dva pozitiva, tri violine, dvije gitare, gitarska lutnja, pet citri i usna harmonika. U fundusu su i četiri glazbena automata. Premda se ova građa nije sustavno sakupljala, o njoj se od samog početka vodila naročita briga. To se u prvome redu može zahvaliti povjesničaru Krešimiru Filiću (1891. - 1972.), utemeljitelju Gradskog muzeja Varaždin, u kojemu je bio prvi profesionalni muzealac i ravnatelj (1925. - 1945.; 1946 - 1957.). Kao ljubitelj i poznavatelj glazbe, autor opsežne studije Glazbeni život Varaždina, ${ }^{4}$ inicirao je održavanje različitih koncerata u muzeju. Tri godine nakon otvorenja, dakle 1928., muzejski postav je proširen s dvije

2 Gradski muzej Varaždin: Povijest muzeja, http://www.gmv.hr/hr/o-muzeju/povijest/. Pristup: 15. svibnja 2018.

3 Zahvaljujem Ljerki Albus, muzejskoj savjetnici Etnografskog odjela Gradskog muzeja Varaždin, na ovim podacima.

4 U tom je radu, objavljenom u povodu 140. obljetnice Glazbene škole, izložio povijest glazbene kulture grada, djelatnost crkvenih i svjetovnih ustanova te glazbenika s popisom skladbi. Krešimir FILIĆ, Glazbeni život Varaždina, Muzička škola Varaždin, Varaždin, 1972. 
prostorije dobivene od gradske općine. Tamo je uređena mala glazbena zbirka i izložen klavir. O tome je Filić u članku Naš varaždinski muzej 1929. zabilježio: „Na desno nalaze se prostorije, koje su uređene prije godinu dana [1928.] i to u jednoj sobi smjestismo zbirku starih novaca, listine, pet portraita iz županije, gradsku željeznu blagajnu, stakleni svjetionik i nešto muzičkih sitnica iz Varaždina (Padovec, Stöhr). Druga soba imade lijepi stari kamin, ovdje su stvari prof. Dr. V. Jagića, slike i druge sitnice koje je poklonio banski savjetnik g. Gustav pl. Koritić iz Zagreba, dalje bidermajerski klavir i vitrina sa staklom i porculanom. " ${ }^{5}$ Dvije godine kasnije (1931.) predstavljena je malo veća glazbena zbirka u sobi u južnom krilu Starog grada.

U članku Muzička zbirka u Padovčevoj kući? objavljenom 1968. Filić piše: „Zbirka je uglavnom obuhvaćala predmete i skladbe Ivana Padovca, zatim prof. Ante Stöhra i Gabrijele Horvatove, razne stare note varaždinskog muzičkog društva, koncertne rasporede iz 19. stoljeća te stari kratki klavir uz nekoliko fotografija skladatelja Varaždinaca. Tim eksponatima htjelo se pokazati da u Varaždinu ima dosta predmeta iz njegove bogate glazbene prošlosti, a da je to samo skromni početak za stvaranje posebnog glazbenog odjeljenja.“6 Filić se zalagao da se prostor Glazbene zbirke uredi u Padovčevoj rodnoj kući. Opisujući predmete koji bi se tamo mogli izložiti, navodi glazbenu građu koja se čuva u GMV-u: „Osim ovih spomenutih predmeta, koji su se nalazili u prvoj muzičkoj zbirci, pridošlo je kasnije u muzej raznih muzikalija: to su originalni muzički rukopis koji je poklonio muzičar pok. Ernest Krajanski, stare tiskane note velikim dijelom dar Nandine Bombelles d'Ansenbourg, zatim kupljeni prijepis Padovčevih skladbi, arhiv pjevačkih društava Vile, Vijenca i Tomislava, kao i njihovi barjaci, razne fotografije i stari klavir - clavecin, postavljen privremeno u zbirci dra Nikole Pečornika. ${ }^{\text {"7 }}$ Filić je predlagao da se u glazbenoj zbirci u Padovčevoj kući sakupe skladbe varaždinskih skladatelja iz uršulinskog i franjevačkog samostana te župne crkve sv. Nikole, kao i to da se Padovčeva deseterostruna gitara pohranjena u Muzeju za umjetnost i obrt u Zagrebu (HGZ 56) možda vrati u Varaždin. Međutim, Filićeva vizionarska ideja nije se realizirala, a stalna glazbena zbirka nije zaživjela ni tada, ni kasnije.

Krešimir FILIĆ, „Naš varaždinski muzej“, Varaždinske novosti, 24. prosinca 1929., br. 3., str. 8.

6 Krešimir FILIĆ, „Muzička zbirka u Padovčevoj kući?”, Vjesnik - varaždinsko izdanje, 19. veljače 1968., br. 7544., str. 11. Tekst je nastao u Varaždinu 6. veljače 1968. Zahvaljujem Jeleni Rančić i na ustupanju Filićeva strojopisa.

7 Isto, str. 11. Clavecin koji Filić spominje vjerojatno je povijesni klavir Michaela Rosenbergera (GMV-KPO 54306), koji je bio postavljen na prvom katu Starog grada (današnji Barok II) u tzv. Bidermajerskoj sobi namještenoj predmetima otkupljenim 1954. od Nikole Pečornika (1867. 1961.), sportskog i kulturnog djelatnika. Klavir nije nabavljen od Pečornika. Zahvaljujem Jeleni Rančić na ovim podacima. 
Zbog nedostatka prostora glazbeni instrumenti iz Glazbene zbirke čuvaju se na nekoliko lokacija: u gotičko-renesansnoj utvrdi Stari grad, baroknoj palači Sermage (povijesni klavir Michaela Rosenbergera) i klasicističkoj palači Herzer (klavir Johanna Prombergera mlađeg). Osim pozitiva Rudolfa Rapoldta i povijesnog klavira Michaela Rosenbergera, ostali instrumenti nisu javno dostupni jer su pohranjeni u čuvaonicama ili drugim teško dostupnim mjestima. Klaviri su u Starom gradu pohranjeni u tavanskoj čuvaonici namještaja sjeverozapadne kule Staroga grada (Cehovske kule), čuvaonici internog naziva Marija Terezija, podrumu ispod stepenica i tehničkom depou za vitrine i stalke. Instrumenti manjih dimenzija - tri violine, dvije gitare, gitarska lutnja, pet citri i usna harmonika - pohranjeni su u tavanskoj čuvaonici Crvene vitrine u Starom gradu. Proteklih godina sustavno se radi na reorganizaciji čuvaonica. Kroz dugogodišnju strategiju cilj je napraviti odgovarajuću pohranu cijelog fundusa pa tako i Glazbene zbirke. Naravno, idealno rješenje bilo bi predstavljanje građe iz Glazbene zbirke u stalnom postavu, koji bi na cjelovit način pružio uvid u bogati glazbeni život grada Varaždina.

U muzejskim knjigama ulaska iz ranijih razdoblja u pojedinim slučajevima nisu bilježeni prijašnji vlasnici instrumenata pa karika koja upućuje na njihov život prije pohrane u muzej nažalost nedostaje. Jeleni Rančić, kustosici Glazbene zbirke, dugujem najveću zahvalnost što me u studenome 2016. provela kroz sve prostore i čuvaonice $u$ kojima su smješteni glazbeni instrumenti te mi dopustila da ih - usprkos poteškoćama vezanim uz njihovu pohranu - pregledam i evidentiram. Osim toga, pružila mi je na uvid u muzejsku dokumentaciju vezanu uz Glazbenu zbirku i glazbene instrumente. To se, uz višekratne razgovore s njom, pokazalo dragocjenim za stvaranje što potpunije slike. Na temelju polaznih indikacija u predmetnim karticama (imena graditelja, mjesta i razdoblja nastanka, dimenzija, sažetog opisa i prijašnjeg vlasnika), poduzeta su daljnja istraživanja povijesti i konteksta uporabe instrumenata te su postojeći podaci dopunjeni zanimljivim pojedinostima vezanima uz njihov život prije ulaska u muzej, ali i stanjem uređenosti i uporabljivosti.

\section{SKUPINA INSTRUMENATA S TIPKAMA}

Skupina instrumenata s tipkama u GMV-u broji deset klavira i dva pozitiva. Riječ je o instrumentima srodnih konstrukcijsko-tehničkih karakteristika koji pripadaju raznovrsnim prethodnicima modernog klavira. Najstariji među njima je stolni klavir koji je između 1790. i 1810. izradio bečki graditelj Johann Jakesch. Ono što skupinu instrumenata s tipkama u GMV-u čini značajnom ne samo za regionalnu već i za nacionalnu kulturnu baštinu jest čak pet povijesnih klavira 
(Hammerklaviera ili Hammerflügela). Svi su tehnički i konstruktivno građeni na isti način. Radi se o tzv. mehanici s otpinjanjem (njem. Prellmechanik), koja je poznata i kao bečka mehanika. Kod ove vrste mehanike tipku je potrebno pustiti do kraja da bi batić ponovno mogao udariti žicu. ${ }^{8}$ Njezin izumitelj bio je njemački graditelj Johann Andreas Stein (1728. - 1792.). Usavršio ju je Johann Andreas Streicher (1761. - 1833.), koji je oženio njegovu kćer Nanette Stein (1769. - 1833.) i s njom u Beču imao radionicu za izradu klavira. Karakteristike za tu vrstu mehanike su sljedeće: drvena konstrukcija okvira instrumenta (željezna konstrukcija pojavljuje se 1825.); batići obloženi pustom i jelenjom kožom, pričvršćeni direktno na osovinu tipke; nijansiranje dinamike (posljedica ležanja batića na tipci); ravne žice (križane žice od 1830.). ${ }^{9}$ Među pet sačuvanih povijesnih klavira su tri čiji su graditelji u prvoj polovici 19. stoljeća bili cijenjeni diljem Europe: Michael Rosenberg i Wilhelm Lange u Beču te Carl Scmidt u Bratislavi. Rosenbergov klavir nastao je oko 1810., Langeov oko 1835. a Schmidtov između 1837. i 1840. Kod druga dva povijesna klavira ime graditelja nije poznato. Instrument koji se čuva pod inv. oznakom GMV-KPO 63436 nastao je između 1810. i 1820., a prema načinu izrade može se pretpostaviti da je bečkog podrijetla. Skraćeni povijesni klavir koji se čuva pod inv. oznakom GMV-KPO 54308 vjerojatno je isto bečkog podrijetla, a nastao je oko 1820.

Na povijesne klavire nadovezuju se četiri klavira izrađena u Beču u drugoj polovici 19. stoljeća. Klavir Carla Kutschere nastao je 1868. ili neposredno nakon toga. Klavir Josefa Kaspara Fritza sagrađen je 1873. ili neposredno nakon toga, klavir Johanna Prombergera mlađeg oko 1875., a klavir braće Carla i Johanna Schweighofera (sinova Johanna Michaela Schweighofera) krajem 1880-ih. Osim klavira, zbirka posjeduje i dva pozitiva. Pozitiv nepoznatog graditelja bio je nabavljen za kapelu u Vukovoju, a potječe iz Štajerske, gdje je nastao između 1600. i 1650. Pozitiv Rudolfa Rapoldta, nastao je u austrijskom gradu Bruck an der Mur 1668., a pripadao je inventaru dvorca Borl na Dravi u Sloveniji.

\section{Stolni klavir (GMV-KPO 63435, slika 1) ${ }^{10}$}

U rujnu 2010. na inicijativu tadašnjeg ravnatelja GMV-a Branka Speveca, djelatnici Konzervatorsko-restauratorskog odjela, kustosi Kulturno-povijesnog

8 Za razliku od bečke, kod kasnije razvijene engleske mehanike tipku je dovoljno otpustiti do otprilike polovice da se batić vrati u položaj spreman za ponovni put prema žici. To omogućava bržu repeticiju pa se ova vrsta mehanike naziva još i repeticionom.

9 Zdenko KUŠĆER, „Zbirka Hammerklavira u Gradskom muzeju Varaždin“, St. Gallen-Varaždin, 2007., studija iz dokumentacije Gradskog muzeja Varaždin (rukopis). Zahvaljujem Jeleni Rančić na njezinu ustupanju.

10 Sve fotografije su u vlasništvu Gradskog muzeja Varaždin uz čije su dopuštenje ovdje objavljene. 
odjela te pomoćni djelatnici (muzejski tehničari i održavateljice čistoće) krenuli su u intervenciju čišćenja tavanskih prostorija sjeverozapadne kule Staroga grada (Cehovske kule). Na tavanu se dugi niz godina odlagao dio fundusa inventiran pri dolasku u muzej. Predmeti su uglavnom bili smješteni po podu, ispod neizoliranog krovišta koje je prokišnjavalo. Intervencija se sastojala od preventivne zaštite (suhog čišćenja, spajanja dijelova, fotografiranja zatečenog stanja), premještanja predmeta $u$ podrum Cehovske kule te njihove sustavne obrade. U ovoj intervenciji ponađeni su stolni klavir (GMV-KPO 63435) i povijesni klavir (GMVKPO 63436), dva prethodnika modernog klavira.

Signatura koja otkriva ime graditelja i mjesto podrijetla ovog stolnog klavira postavljena je iznad klavijature u obliku ovalne porculanske pločice. Iako je značajno oštećena, na njoj se vide slova "J... kesch / Wien", na temelju čega se može rekonstruirati da je cjelovit natpis bio „Johann Jakesch / in Wien“" (,Johann Jakesch / u Beču“). Graditelj klavira Johann Jakesch (Jakisch, Jaksch; 1763. - 1840.) bio je podrijetlom iz Malhostovica u južnoj Moravskoj. ${ }^{11}$ Nije poznato kada i gdje se školovao. Status građanina Beča dodijeljen mu je 1793. U dokumentu iz 1799. spominje se kao „Bürgerlicher Instrumentmacher“, odnosno građanin Beča i graditelj instrumenata. U arhivskim spisima zabilježeno je da je 1803. bio vlasnik kuće u Beču, a 1810. da je pristupio cehu graditelja instrumenata. Ludwig van Beethoven u pismu upućenom prijatelju Nikolausu Zmeskallu 1802. spominje da u svome domu ima Jakeschov klavir, iako je bilo poznato da je preferirao klavire Antona Waltera. ${ }^{12}$ Kao graditelji klavira u Beču djelovali su njegov sin Georg Jakob Jakesch (1791. - 1846.) te nećaci Mathias Jakesch (oko 1783. - [oko] 1828.), Ignaz Jakesch (1785. - 1816.) i Franz Jakesch (1803. - ?). Jakeschovi klaviri u obliku krila zabilježeni su u nekoliko zbirki: Zbirci povijesnih glazbenih instrumenata Muzeja povijesti umjetnosti u Beču (u vlasništou tamošnjeg Društva prijatelja glazbe), Univerzalnom muzeju Joanneum u Grazu, Muzeju Händel-Haus u Halleu, ${ }^{13}{ }^{\text {SSle- }}$ skom muzeju u Opavi, ${ }^{14}$ Fondazione Teatro Massimo u Palermu ${ }^{15 i d r .}$

11 Malhostovice (njem. Malostowitz) se nalaze $6 \mathrm{~km}$ istočno od grada Tišnova i pripadaju okrugu Brno-venkov.

12 Rudolf HOPFNER, "Jakesch (Jakisch, Jaksch), Familie“, Oesterreichisches Musiklexikon Online, http://www.musiklexikon.ac.at/ml/musik_j/jakesch_familie.xml. Pristup: 15. svibnja 2018.

13 Richard MAUNDER, Keyboard Instruments in Eighteenth-Century Vienna, Clarendon Press, Oxford, 1998., 83 i 206.

14 Clinkscale Online: A Comprehensive Database of Early Pianos, 1700-1860: CEP-2695, http:// earlypianos.org/. Pristup: 15. svibnja 2018.

15 Giovanni Paolo DI STEFANO, Selima Giorgia GIULIANO, Sandra PROTO, ur., Strumenti musicali in Sicilia, CRicd Regione Siciliana, Palermo, 2013., 198-199. 
Za stolni klavir Johanna Jakescha u GMV-u može se pretpostaviti da je nastao između 1790. i 1810. godine. Dimenzije su mu 161 x 33 x $83 \mathrm{~cm} .{ }^{16}$ Kućište u obliku četverokutne kutije zaobljenih rubova i poklopac nad njom izrađeni su od smrekovine te su obloženi politiranim furnirom od orahovine. Rezonantna ploča je od smrekovine, a ugradbena greda od javorovine. Zbog konstruktivnog učvršćenja je po sredini uzdužnog presjeka, između ugodbene i nosive poprečne grede, postavljena željezna greda. Klavir ima drvenu konstrukciju s ravnim žicama postavljenim horizontalno i dijagonalno u odnosu na klavijaturu. Opseg klavijature je od $\mathrm{C}_{1}$ do $\mathrm{a}_{4}$ (šest oktava i velika seksta). Tipke su načinjene od smrekovine. Oblozi donjih tipaka su od kosti (mnogi nedostaju), a gornjih tipaka od orahovine. Donje tipke stoga su bijele boje, a gornje crne. Kod ovog klavira susrećemo bečku mehaniku s otpinjanjem s vilicama (vodilicama batića) od mjedi te hvatačima batića. Žice su grupirane na sljedeći način: od $\mathrm{F}_{1}$ do $\mathrm{H}_{1}$ po jedna žica; od $\mathrm{C}$ do $\mathrm{h}_{2}$ po dvije žice $\mathrm{u}$ koru; od $\mathrm{c}_{3}$ do $\mathrm{a}_{4}$ po 3 žice u koru. Duljina srednje žice na tonu $c_{2}$ iznosi $261 \mathrm{~mm}$. Vijci su željezni, pravokutnog oblika; na nekima su probušene rupice. Klavir je teško oštećen i necjelovit. Od većih funkcionalnih i konstruktivno-tehničkih elemenata nedostaju: tri od ukupno četiri tokarene profilirane noge, lira s dvjema pedalama, poklopac nad klavijaturom, stalak za note, cjelokupni ustroj utišača $\left(C_{1}-\right.$ gis $\left._{3}\right)$ i letva s hvatačima batića. Konstruktivni dijelovi su se razlijepili pa su na površini vidljiva mehanička oštećenja furnira. Završna politura je posve oštećena. Rezonantna kutija je napukla.

Ovo je vrijedan instrument u kontekstu bečke graditeljske tradicije s prijelaza 18. u 19. stoljeće. Njegovo današnje stanje zahtijeva cjelovitu obnovu, kako unutrašnjosti tako i kućišta. Za to je u Konzervatorsko-restauratorskom odjelu GMVa načinjen prijedlog obnove s opisom instrumenta i zatečenog stanja. U prosincu 2010. klavir je otpremljen u Umjetničku radionicu Heferer u Zagrebu s namjerom da se izvrši temeljita i sveobuhvatna obnova.

16 Kod svih klavira dimenzije su navedene na sljedeći način: širina $x$ duljina $x$ visina. 


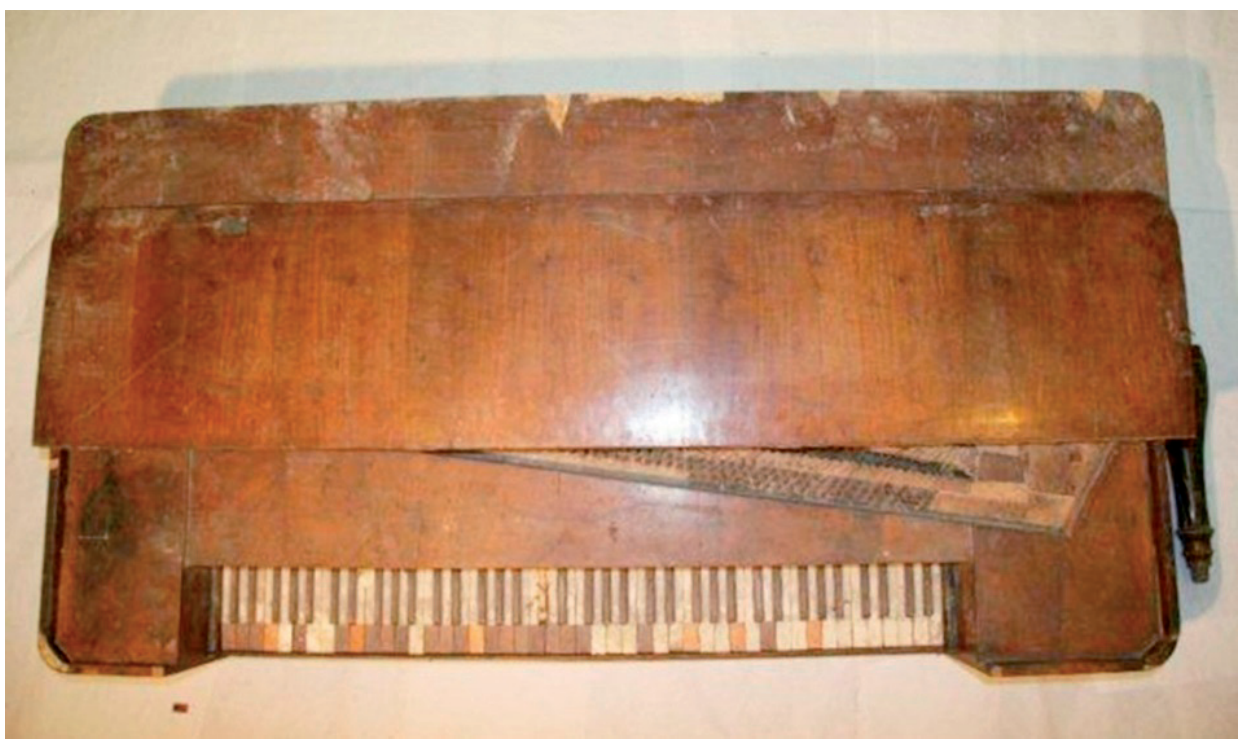

Slika 1. Stolni klavir (GMV-KPO 63435), Johann Jakesch, Beč, između 1790. i 1810.

\section{Povijesni klavir (GMV-KPO 54306, slika 2)}

Naziv Hammerklavier ili Hammerflügel pojavio se početkom 19. stoljeća u Austriji i Njemačkoj, a označavao je klavir kod kojeg batići udarcem o žice proizvode zvuk. Bilo je to u jeku borbe protiv tuđica, a trebao je zamijeniti talijanski pianoforte. Ludwig van Beethoven je u naslovu svojih klavirskih sonata op. $101 \mathrm{i}$ op. 106 (koje su nastale 1816., odnosno 1818.) posebno naznačio da su skladane za Hammerklavier, premda su i njegove ostale klavirske sonate skladane za taj instrument (a ne za čembalo). Drveni korpus ovog instrumenta ima oblik krila. Izrađen je od smrekovine, obložen furnirom od orahovine i politiran. Odozdo je zatvoren smrekovim daskama. Uzak i dugačak (dimenzija 113 × 220 x 91,5 cm), stoji na četiri vitke četverostrane noge. Tri su noge sprijeda, jedna straga, a pri krajevima se lagano sužavaju. Iznad klavijature smještena je pločica uokvirena mjedenim okvirom s bijelom podlogom. Crnim tušem na njoj je ispisano „Michael Rosenberger / Bürger in Wien“ („Michael Rosenberger / građanin u Beču“). Time saznajemo da ga je u Beču sagradio Michael Rosenberger (1766. - 1832.), podrijetlom iz Bavarske. On je gradnju klavira učio kod bečkog graditelja Antona Waltera (1752. - 1826.). Građaninom Beča proglašen je 1796. Njegovi klaviri od- 
likuju se bečkom mehanikom i izgledom tipičnim za početak 19. stoljeća. Raniji klaviri, nastali između 1800. i 1810., imaju dvije pedale koje se pokreću koljenom te opseg klavijature od $5\left(\mathrm{~F}_{1}-\mathrm{g}_{3}\right)$ ili 51/2 oktava $\left(\mathrm{F}_{1}-\mathrm{c}_{4}\right)$. Od 1810. gradio je klavire $\mathrm{s}$ opsegom klavijature od šest oktava $\left(\mathrm{F}_{1}-\mathrm{f}_{4}\right)$, koji su imali do čak šest pedala. ${ }^{17}$ Prema detaljima vezanima uz mehaniku i opsegu klavijature od šest oktava $\left(\mathrm{F}_{1}-\mathrm{f}_{4}\right)$, može se pretpostaviti da je ovaj klavir nastao oko 1810. Donje tipke su bijele boje, obložene bjelokošću, a gornje crne, prekrivene tankom ebanovinom. Poklopac nad instrumentom ima dva preklopa jer je klavijatura ugrađena u korpus. Kod ovog klavira susrećemo bečku mehaniku s otpinjanjem s vilicama (vodilicama batića) od mjedi te hvatačima batića. Drvene je konstrukcije s ravnim žicama. Žice su ustrojene na sljedeći način: od $\mathrm{F}_{1}$ do $\mathrm{b}_{1}$ su po dvije žice $\mathrm{u}$ koru, a od $\mathrm{c}_{2}$ do $\mathrm{f}_{4}$ po tri žice $\mathrm{u}$ koru. Rezonantna ploča je izrađena od smrekovine, a ugradbena greda od javorovine. Zbog konstruktivnog učvršćenja je po sredini uzdužnog presjeka, između ugodbene grede i nosive poprečne grede, postavljena željezna greda. Klavir ima četiri pedale koje se pokreću koljenom: fagot, forte, piano (jednostruki moderator) i pianissimo (dvostruki moderator). Visina ugodbe za ton $\mathrm{a}_{1}$ iznosi $415 \mathrm{~Hz} .^{18}$

Ovaj Rosenbergerov klavir pronađen je na tavanu GMV-a u vrlo lošem stanju. Prepoznat je i procijenjen kao izvorni primjerak te vrste klavira izrađen $u$ Beču tijekom razdoblja bečke klasike. Smatra ga se osobito vrijednim jer je u Hrvatskoj jedan od malobrojnih izvorno sačuvanih primjeraka bečke gradnje instrumenata s tipkama kraja 18. i početka 19. stoljeća. Uz to, ovaj Rosenbergerov klavir jedino je poznato i očuvano djelo tog graditelja u Hrvatskoj. Njegovi instrumenti zabilježeni su još u nekoliko zbirki: Zbirci povijesnih glazbenih instrumenata Muzeja povijesti umjetnosti u Beču, Glazbenom muzeju Finchcocks u Kentu na jugoistoku Engleske ${ }^{19}$ te u Zbirci instrumenata s tipkama Fritza Neumeyera u njemačkom gradiću Bad Krozingenu u blizini Freiburga. ${ }^{20}$ Uz to, čuvaju se u Muzeju glazbenih instrumenata u dvorcu Sforzecso u Milanu, ${ }^{21}$ Visokoj školi za glazbu i primijenjenu umjetnost

17 Michael LATCHAM, „Rosenberger“, Oxford Music Online. Grove Music Online, http://www. oxfordmusiconline.com/grovemusic/view/10.1093/gmo/9781561592630.001.0001/omo9781561592630-e-4002291433. Pristup: 15. svibnja 2018.

18 Bosiljka PERIĆ KEMPF, Povijesni klavir Hammerflügel: Michael Rosenberger: Bürger in Wien, Gradski muzej Varaždin-Atelier Heferer, Varaždin, 2010., 17.

19 Finchcocks Musical Museum: The Richard Burnett Heritage Collection, http://www. finchcocks.co.uk/collection.html. Pristup: 15. svibnja 2018.

20 Bosiljka PERIĆ KEMPF, „Rosenbergerov Hammerflügel: dio svjetskoga kulturnog nasljeđa“ , $P_{0}$ vijesni klavir Hammerflügel: Michael Rosenberger: Bürger in Wien, 1-4.

${ }^{21}$ Clinkscale Online: A Comprehensive Database of Early Pianos, 1700-1860: CEP-2695, http:// earlypianos.org/. Pristup: 15. svibnja 2018. 
u Beču, Muzeju povijesti glazbe u Budimpešti, ${ }^{22}$ Međunarodnom centru pianofortea Ad Libitum u Étobonu na istoku Francuske, ${ }^{23}$ Zbirci Edwina Beunka u Enschedeu na istoku Nizozemske, ${ }^{24}$ Nacionalnom glazbenom muzeju Sveučilišta Sjeverne Dakote u Vermillionu ${ }^{25}$ i drugdje.

Stanje varaždinskog instrumenta zahtijevalo je brižljivu obnovu koja je 2008. povjerena Umjetničkoj radionici Heferer u Zagrebu. Instrumentu su nedostajale noge i stalak za note, nije imao mehaniku za pedale, a uz više drugih oštećenja isticala se pukotina na donjoj strani rezonantne ploče. Temeljiti restauratorsko-rekonstrukcijski radovi obuhvaćali su uređenje vanjštine, akustički ustroj instrumenta, sanaciju mehanike, uređenje klavijature, ugradnju nedostajućih dijelova te funkcionalno i foničko oblikovanje. ${ }^{26}$ Sredstva za obnovu osigurali su Ministarstvo kulture Republike Hrvatske, Grad Varaždin i Varaždinska županija. Restaurirani Rosenbergerov klavir javnosti je predstavljen 2009. Na prigodnom koncertu 8. prosinca 2009. u palači Sermage nastupio je ansambl Camerata Garestin, a na klaviru je svirao čembalist i pijanist Krešimir Has. Uz njega su nastupili Ivana Lazar, sopran; Dani Bošnjak, poprečna flauta te Krešimir Lazar, barokni violončelo. Na programu su bila djela J. Haydna, W. A. Mozarta, G. F. Händela i M. Clementija. ${ }^{27}$ O klaviru je objavljena i knjižica pod naslovom Povijesni klavir Hammerflügel: Michael Rosenberger: Bürger in Wien. ${ }^{28}$ Nakon toga je klavir zazvučao na koncertima Varaždinskih baroknih večeri. Ovaj klavir, kao dio kulturno-spomeničke baštine grada Varaždina, pridonosi njegovanju povijesno osviještene interpretacije klavirske i komorne glazbe kasnog 18. i početka 19. stoljeća. Kao takav ima važnu ulogu u koncertnom životu Varaždina. Rosenbergerov povijesni klavir upravo je idealan primjer brige, čuvanja i upotrebe glazbenog instrumenta u nekoj muzejskoj zbirci.

22 Michael LATCHAM, The Stringing, Scaling and Pitch of Hammerflügel built in the Southern German and Viennese traditions 1780-1820, Musikverlag Katzbichler, München - Salzburg, 2000., xviii.

23 Centre International du Pianoforte Ad Libitum: Collection, http://www.pianoforteadlibitum.org/ collection/. Pristup: 15. svibnja 2018.

24 Edwin Beunk Collection: Collection, http://www.fortepiano.nl/pages/73773/Collection.html. Pristup: 15. svibnja 2018.

25 Clinkscale Online: A Comprehensive Database of Early Pianos, 1700-1860: CEP-8122, http:// earlypianos.org/. Pristup: 15. svibnja 2018.

26 B. PERIĆ KEMPF, Povijesni klavir Hammerflügel: Michael Rosenberger: Bürger in Wien, 6 i 18.

27 Gradski muzej Varaždin: Predstavljanje obnovljenog Hammerklaviera iz fundusa GMV-a, http:// www.gmv.hr/hr/dogadjanja/predstavljanje-obnovljenog-hammerklaviera-iz-fundusa-gmv-a, 2059.html?t=d. Pristup: 15. svibnja 2018.

28 Bosiljka PERIĆ KEMPF, Povijesni klavir Hammerflügel: Michael Rosenberger: Bürger in Wien, Gradski muzej Varaždin-Atelier Heferer, Varaždin, 2010. 


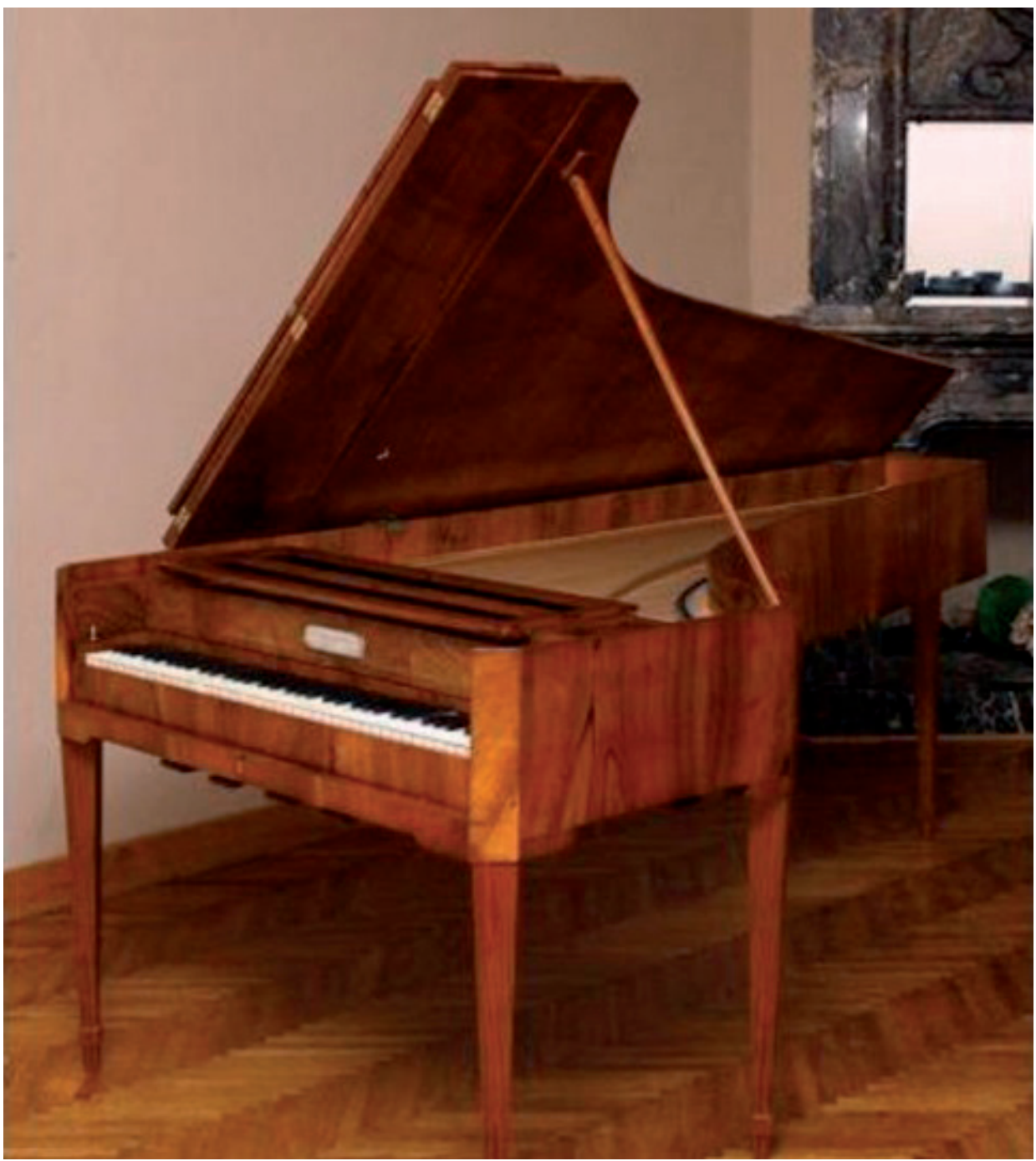

Slika 2. Povijesni klavir (GMV-KPO 54306), Michael Rosenberger, Beč, oko 1810.

\section{Povijesni klavir (GMV-KPO 63436, slike 3 i 4)}

Ovaj klavir, zasada nepoznatog graditelja, povijesni je instrument iz fundusa GMV-a. Nastao je između 1810. i 1820., a prema mehanici i gradbeno-oblikovnim elementima može se pretpostaviti da je bečkog podrijetla. Za nacionalnu kulturnu baštinu od osobitog je značenja jer je pripadao hrvatskom banu Josipu 
Jelačiću (1801. - 1859.). Na to ukazuje zapis koji je bio zalijepljen s unutarnje strane poklopca. Poruka je pažljivo uklonjena sa poklopca te je na njoj u Hrvatskom državnom arhivu 2010. proveden konzervatorsko-restauratorski postupak. Mjestimično je nepovratno oštećena, a sačuvani zapis glasi:

„Ovaj klavir (spinet) bio je ...

Jelačića bana, koji ga je dao ...

beniku Peschke-u, a ovaj je dosel ...

Vinicu dao ga učitelju u Petrijanec ...

Cvetku Juraju, a od ovoga kupio ga

Ladika Ferdo, učitelj u Maruševcu

god. 1890. za 20 for.

Zabilježio sin Ferde Ladike

Bogumil Ladika, viećnik

Banskog stola u m. u Vinici 9. travnja 1941.“29

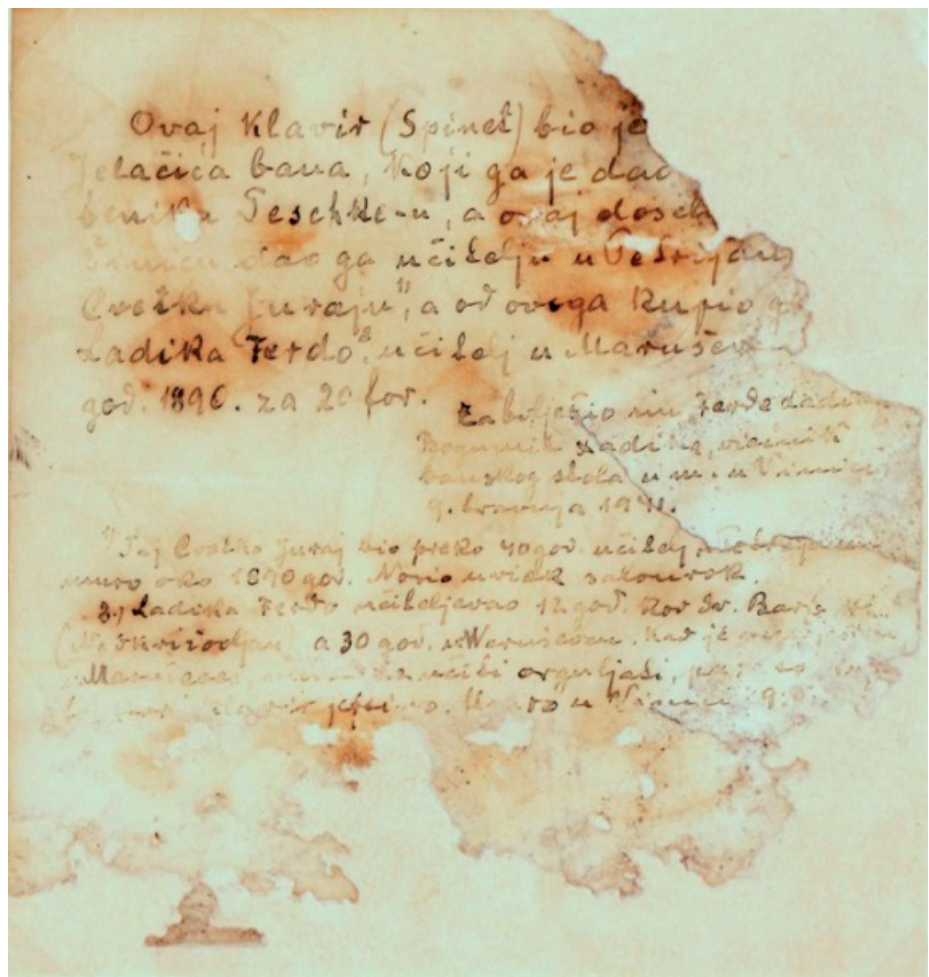

Slika 3. Zapis s povijesnog klavira (GMV-KPO 63436)

29 Transliteracija teksta preuzeta je s predmetne kartice ovog klavira uz provjeru s izvorom. 
Na klaviru je možda mogla svirati banica Sofija Jelačić (rođ. Stockau; 1834. 1877.), moravska grofica njemačkog podrijetla. Budući da je bila plemkinja može se pretpostaviti da su glazba i sviranje klavira bili sastavni dijelovi njezina obrazovanja. S banom Jelačićem vjenčala se 22. srpnja 1850. u njezinu rodnom gradiću Napajedla u regiji Zlín u Moravskoj. Svojim skromnim ponašanjem i mladenačkim poletom, bila je omiljena u hrvatskoj javnosti. ${ }^{30}$ Ostala je zabilježena i kao pokroviteljica Hrvatskog glazbenog zavoda od 1852. do 1860. godine. ${ }^{31}$ Nakon smrti bana Jelačića u svibnju 1859., Sofija je samo još kraće vrijeme živjela u Novim dvorima. Nakon četverogodišnje korote vratila se u Moravsku i 1863. preudala za grofa Adolfa Dubskog. Ugovorom od 23. ožujka 1863. imanje je pripalo banovu bratu Đuri Jelačiću, koji ju je morao isplatiti s 30000 forinti. S novim suprugom živjela je u Beču do smrti 1877. godine. ${ }^{32}$

Ban Jelačić je, poput svoje supruge, bio glazbeno obrazovan budući da je svirao klavir i pjevao. ${ }^{33}$ Napisao je stihove za popijevku Kakva mora moja djeva bit'? koju je uglazbio Ferdo Livadić. Bio je podupirući član Hrvatskog glazbenog zavoda od 1848. do 1859. godine. ${ }^{34}$ Iskazao se zauzimanjem i prijateljskim postupcima prema Vatroslavu Lisinskom. Pismom od 11. kolovoza 1850. molio je tadašnjeg pokrovitelja praškoga konzervatorija Kamila Rohana da utječe na Društvo za gajenje glazbe te dopusti Lisinskom pristup ispitu na konzervatoriju radi stjecanja diplome, nakon trogodišnjeg privatnog naukovanja kod Jana Bedřicha Kittla. Usprkos banovu posredovanju Lisinskome nije bilo omogućeno polaganje ispita. Lisinski mu je još 1848. posvetio zborsku skladbu naslovljenu Jelačić ban..$^{35}$ Brojni književnici su Jelačiću u čast spjevali više prigodnica, popijevki i soneta (Ivan Trnski, Pavao Štoos, Antun Kaznačić, Petar Preradović, Josip Runjanin, Franz Grillparzer, Vladimir Nazor i dr.). U njegovu čast koračnice su skladali Karlo Hilleprand von Prandau (Beč, 1848.?) i Johann Strauss stariji (op. 244; Beč, 1849.). ${ }^{36}$ Na obljetnicu Jelačićeve smrti 20. svibnja 1870. izveden je Requiem za sole,

30 Lovorka ČORALIĆ, „Hrvatska banica - Sofija Stockau Jelačić (1834.-1877.)“, Godišnjak Njemačke narodnosne zajednice - VDG Jahrbuch, 3, Osijek, 1997, 100.

31 Ladislav ŠABAN, 150 godina Hrvatskog glazbenog zavoda, Hrvatski glazbeni zavod, Zagreb, 1982., 209 i slikovni prilog $X$.

32 L. ČORALIĆ, $n$. dj., 105-106.

33 Vlasta ŠVOGER, „Ban Josip Jelačić u očima svojih suvremenika“, Zbornik Odsjeka za povijesne znanosti Zavoda za povijesne $i$ društvene znanosti Hrvatske akademije znanosti $i$ umjetnosti, 31, Zagreb, 2013, 248-294.

$34 \quad$ L. ŠABAN, $n$. dj., 51-52.

35 Lovro ŽUPANOVIĆ, Vatroslav Lisinski (1819-1854): život, djelo, značenje, Jugoslavenska akademija znanosti i umjetnosti, Zagreb, 1969., 82-83, bilješka 289.

36 Nikša STANČIĆ, "Jelačić, Josip", Hrvatski biografski leksikon, ur. Trpimir MACAN, Leksikografski zavod Miroslava Krleže, Zagreb, 2005., sv. 6, 394-401. Usp. i V. ŠVOGER, n. dj., 263-264. 
mješoviti zbor, gudački orkestar i orgulje, op. 244, Ivana Zajca, koji se u skladateljevu popisu navodi kao Jelačić Requiem. ${ }^{37}$

Daljnje istraživanje zapisa na klaviru dovelo je do otkrića zanimljivih detalja. Odgovor na pitanje tko je bio spomenuti [benik $\rightarrow$ glazbenik?] Peschke mogao bi pružiti članak Hrvatskim epigonima 1923., objavljen u tjedniku Narodno jedinstvo 6. siječnja 1923. Tamo je, uz opis Jelačićevih ratnih priprema u Cerju Tužnom kraj Varaždina 1848., zabilježeno:

„29. VI. [1848.] podjeljuje hrvatski sabor svome narodnome banu Jelačiću neograničena prava i ovim danom počima Jelačić sa naoružavanjem vojske. On sakupi oko 40000 vojnika u okolici Varaždina i izrađuje u dvorcu Cerje Tužno (vlastelin Peschke, njegov kum) svoj ratni plan protiv Madjarske, a 10. IX. otpočele su operacije i 11. IX. prešao je Jelačić Dravu kod Varaždina. “38

Ovdje je vjerojatno riječ o grofu Vinku Peschkeu starijem, vlastelinu češkog podrijetla koji je bio vlasnik posjeda u Cerju Tužnom i Vinici ${ }^{39}$ u okolici Varaždina. Ako se zaista radilo o kumu bana Jelačića, onda je nasljedstvo klavira u pismu logično i moguće. Njegov sin Vinko Peschke mlađi bio je upravitelj dvorca grofa Jurja Feštetića (Festetića) u Pribislavcu. ${ }^{40}$ Bio je i istaknuti dobrotvor. U svojoj kuriji u Cerju Tužnom otvorio je 1895. osnovnu školu koju su pohađala djeca iz Lukavca i Cerja Tužnog. Djelovala je sve do 1912. kada je otvorena škola u Stažnjevcu. Vinko Peschke mlađi bio je posljednji vlasnik posjeda u Cerju Tužnom. ${ }^{41}$ Umro je od upale pluća u dobi od 62 godine u Čakovcu 30. prosinca 1922. Pokopan je u Vinici dan kasnije. ${ }^{42}$

Kao što sugerira zapis na klaviru, njegov otac Vinko Peschke dao ga je učitelju Juraju Cvetku, on ga je prodao učitelju Ferdu Ladiki, a njegov sin Bogumil Ladika (koji je bio sudbeni vijećnik) darovao Gradskom muzeju Varaždin. O Cvetku je Bogumil Ladika u zapisu na klaviru u bilješci 1 (koju naziva fusnotom) zabilježio: „Taj Cvetko Juraj bio je preko 40 godina učitelj u Petrijancu, umro oko 1890. god“. U bilješci (fusnoti) 2 izneseni su detalji o Ferdu Ladiki, pri čemu neki

37 Hubert PETTAN, Popis skladbi Ivana Zajca, Jugoslavenska akademija znanosti i umjetnosti, Zagreb, 1956., 85 i 358.

38 „Hrvatskim epigonima 1923.", Narodno jedinstvo, 6. siječnja 1926., br. 1., str. 1-2.

39 O dvorcu u Vinici usp. M. OBAD ŠĆITAROCI, n. dj., 300-303.

40 Danas općina u Međimurskoj županiji ustanovljena 2002. izdvajanjem iz grada Čakovca.

${ }_{41}$ Martin LUKAVEČKI, "Cerska lipa - svjedok povijesnog događaja“, 30 dana, 25. ožujka 2016., br. 18., str. $40-41$.

42 „Domaće vijesti“", Narodno jedinstvo, 6. siječnja 1923., br. 1., str. 4. 
dijelovi nedostaju: „Ladika Ferdo koji je 12 godina učiteljevao kod sv. Barbare (Nad Križovljan), a 30 god. u Maruševcu. Kad je premješten u Maruševac ... učiti orguljati, pa ... klavir jeftino." Ferdo Ladika umro je u lipnju 1926. u dobi od 74 godine te je pokopan na groblju u Vinici. ${ }^{43}$ Zahvaljujući zapisu na klaviru poznata su tri mjesta na kojima se sigurno zatekao prije pohrane u Gradski muzej Varaždin: Petrijanec, Maruševec i Vinica.

Klavir ima dimenzije 118,3 x 177 x 30,5 cm (visina bez nogu). Kućište i poklopac izrađeni su od smrekovine i obloženi politiranim furnirom od orahovine. Rezonantna ploča je od smrekovine, a ugradbena greda od javorovine. Zbog konstruktivnog učvršćenja je po sredini uzdužnog presjeka postavljena željezna greda. Poklopac je s unutarnje strane obložen javorovim furnirom. S donje je strane zatvoren smrekovim daskama. Klavir ima drvenu konstrukciju s ravnim žicama postavljenim horizontalno na klavijaturu. Opseg klavijature iznosi 6 oktava $\left(\mathrm{F}_{1}-\mathrm{f}_{4}\right)$. Tipke su od smrekovine. Oblozi donjih tipaka su od kosti (sačuvalo ih se samo šest), a gornjih od ebanovine. Donje tipke stoga su bijele boje, a gornje crne. I kod ovog klavira susrećemo bečku mehaniku s otpinjanjem s vilicama od mjedi te hvatačima batića. Žice su grupirane na sljedeći način: od $\mathrm{F}_{1}$ do $\mathrm{A}_{1}$ po jedna žica; od $\mathrm{C}$ do $\mathrm{f}_{1}$ po dvije žice $\mathrm{u}$ koru; od fis ${ }_{1}$ do $\mathrm{f}_{4}$ po 3 žice u koru. Klavir je teško oštećen. Od većih funkcionalnih i konstruktivno-tehničkih elemenata nedostaju sve tri noge, lira s trima pedalama, poklopac nad klavijaturom, stalak za note i bočni rubnici na klavijaturi. Konstruktivni dijelovi su se razlijepili pa su na površini vidljiva veća mehanička oštećenja furnira. Kućište i unutrašnjost instrumenta su oštećeni djelovanjem vlage i oborinskih voda tako da su metalni dijelovi korodirali, a drveni su oštećeni djelovanjem gljivica. Drvene dijelove su osim toga oštetili crvi i glodavci. Završna politura je posve oštećena. Rezonantna kutija je napukla.

Uz to što je vrijedan klavir u kontekstu bečke graditeljske tradicije s početka 19. stoljeća, posebnu mu vrijednost i značaj za nacionalnu baštinu daje činjenica da je bio u vlasništvu bana Josipa Jelačića. Njegovo devastirano stanje zahtijevalo je cjelovitu obnovu, kako unutrašnjosti tako i kućišta. Za to je u Konzervatorskorestauratorskom odjelu GMV-a načinjen prijedlog obnove s opisom instrumenta i zatečenog stanja. U prosincu 2010. klavir je otpremljen u Umjetničku radionicu Heferer u Zagrebu. Nakon konzervatorsko-restauratorskih radova mogao bi se izložiti u stalnom postavu. Stavljanjem u koncertnu funkciju ovo bi mogao biti treći povijesni instrument iz fundusa GMV-a kojim bi se mogla obogatiti glazbena ponuda Varaždina. Uz Rosenbergerov klavir i Rapoldtov pozitiv, na njemu bi se moglo muzicirati prilikom redovite djelatnosti (otvorenja izložbi) ili u po-

43 "Domaće vijesti“, Narodno jedinstvo, 10. lipnja 1926., br. 22., str. 2. 
sebnim prilikama (npr. Varaždinskim muzejskim svečanostima - tradicionalnom godišnjem događanju koje se priređuje u muzejskim prostorima).

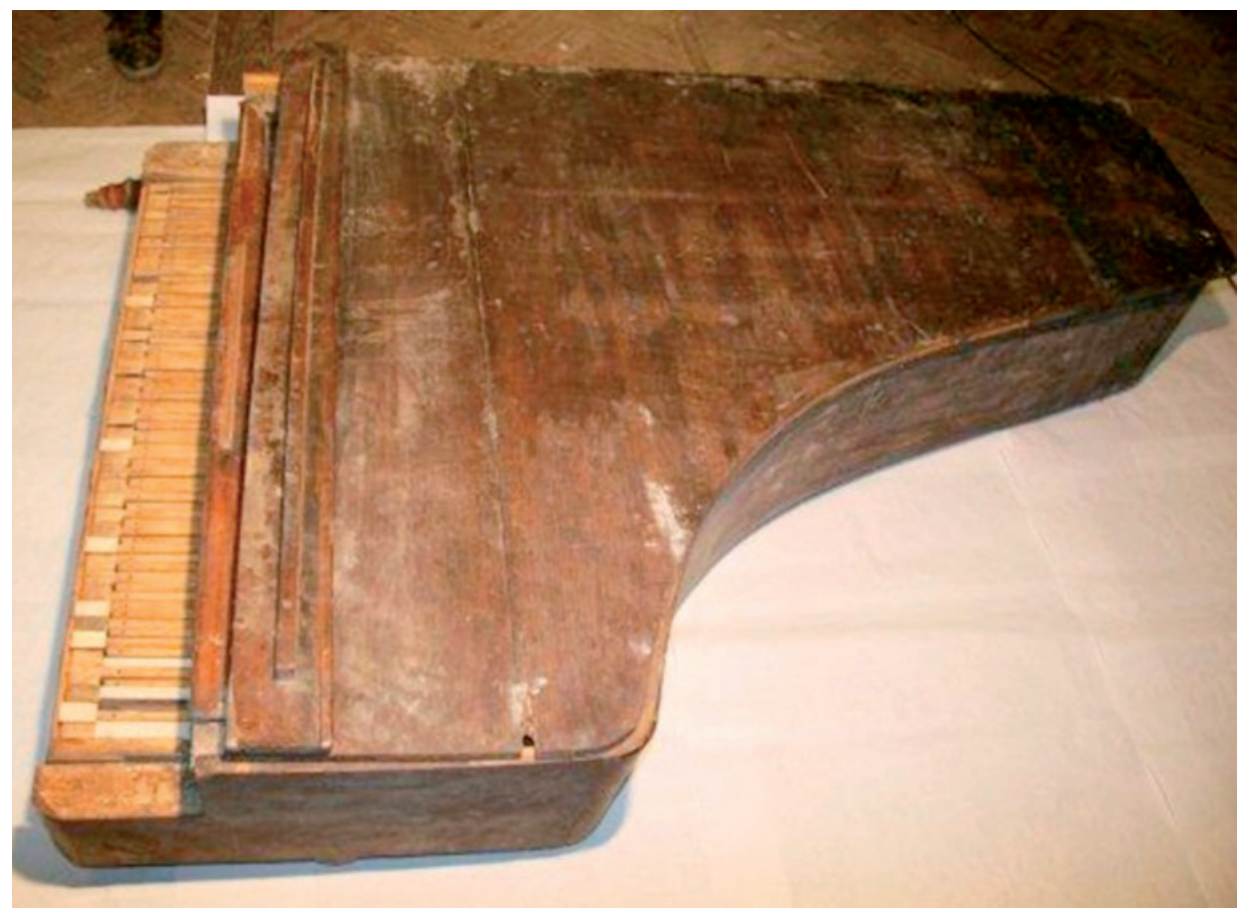

Slika 4. Povijesni klavir (GMV-KPO 63436), nepoznati graditelj,

Beč, između 1810. i 1820.

\section{Povijesni klavir (GMV-KPO 54308, slika 5)}

U čuvaonici internog naziva Marija Terezija u Starom gradu smješten je skraćeni povijesni klavir. Dimenzije su mu 121 x 173 x 32 cm (visina bez nogu). Izrađen je od mekog drva i obložen politiranim furnirom. Stražnji dio je zaobljen. Okrenut je na bok ispod kojeg je postavljen stiropor. Oštećen je i necjelovit. Četvrtasta pločica iznad klavijature na kojoj je bila zapisana signatura je otpala pa ime graditelja nije poznato. Nedostaju noge (vjerojatno kružnog presjeka) te lira s pedalama. Poklopac nad klavijaturom, kao i onaj nad instrumentom, odvojeni su od njega. Instrumentalni ustroj je također oštećen. Klavijatura ima opseg od $C_{1}$ do $\mathrm{f}_{4}$ (šest oktava i čista kvarta). Donje tipke imaju obloge od bjelokosti (neki su oštećeni), a gornje su izrađene od ebanovine. Stalak za note je pravokutnog obli- 
ka s horizontalnom i okomitom prečkom po sredini. Prema izgledu i gradbenooblikovnim elementima može se pretpostaviti da je bečkog podrijetla, vjerojatno nastao oko 1820. U kasnijem je razdoblju vjerojatno skraćen. Zbog lošeg stanja i nepristupačnog smještaja nije ga bilo moguće detaljnije pogledati. U razdoblju od 1965. do 1975. vjerojatno je bio izložen u Starom gradu na prvom katu u dvorani Barok II.

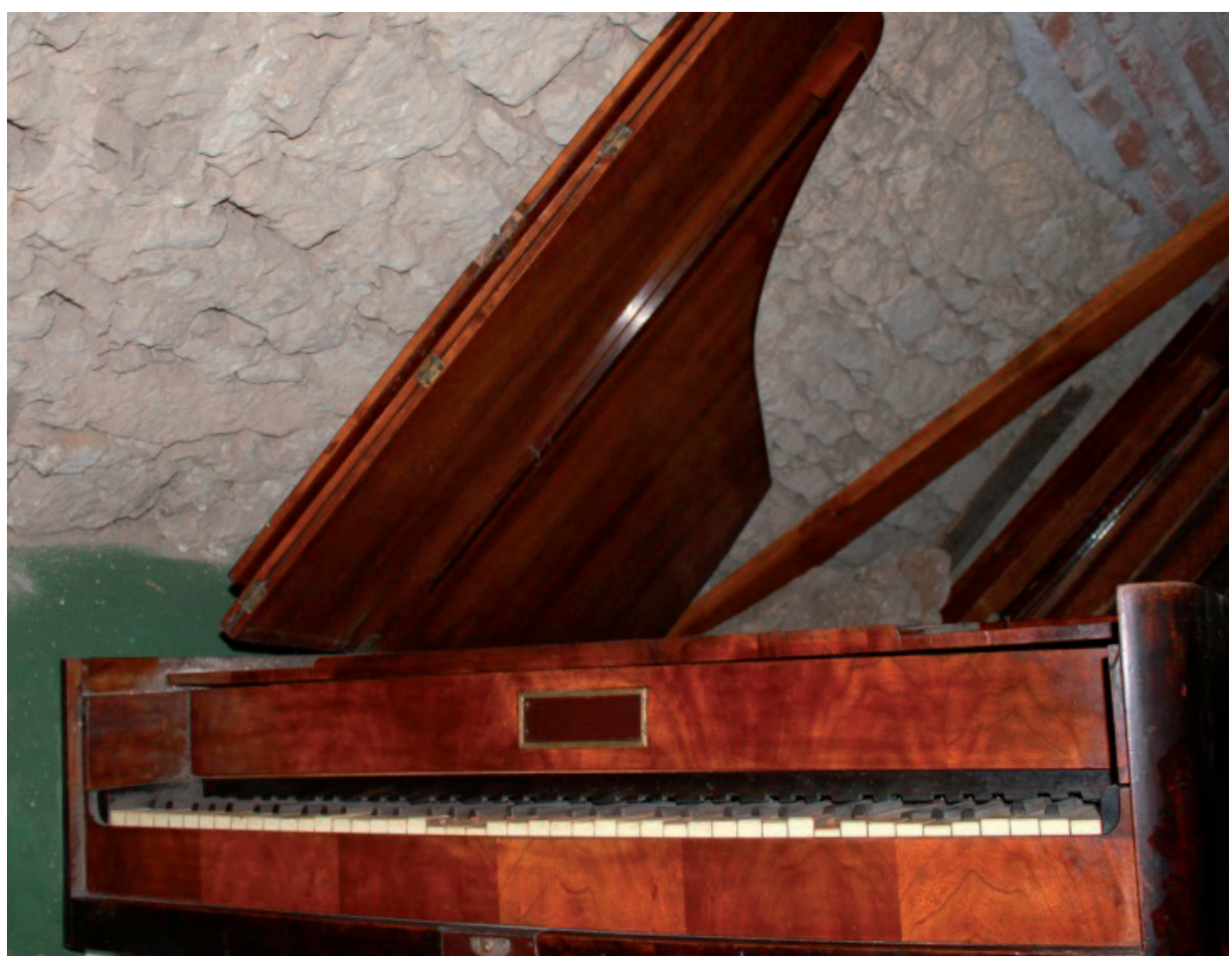

Slika 5. Povijesni klavir (GMV-KPO 54308), nepoznati graditelj, vjerojatno Beč, oko 1820.

\section{Povijesni klavir GMV-KPO 54307, slika 6)}

U čuvaonici internog naziva Marija Terezija u Starom gradu čuva se i povijesni klavir dimenzija 115 x 240 x 34 cm (visina bez nogu). Njegov uzak i dugačak korpus obložen je furnirom od orahovine. Na sredini prednje plohe iznad klavijature, u ukrasnom mjedenom okviru, nalazi se bijela četvrtasta porculanska pločica sa signaturom „Wilhelm Lange / in Wien“ („Wilhelm Lange / u Beču“). 
Na temelju nje saznajemo da ga je sagradio Wilhelm Lange, koji je $\mathrm{u}$ austrijskoj prijestolnici djelovao od 1822. do 1857 . (ili nedugo nakon toga). ${ }^{44}$ Od 1829 . vodio je i malu izdavačku kuću smještenu na adresi Spiegelgasse br. 1098. Za njega je na obrtničkoj izložbi u Beču 1839. zabilježeno: „Izložbeni broj 706. Wilhelm Lange, graditelj klavira iz Beča, Windmühl br. 59, izložio je fortepiano od orahovine i time stekao naklonost stručnjaka i časni spomen. ${ }^{45}$ Njegovi klaviri koji su nastali između 1840. i 1850. najčešće su imali opseg klavijature od sedam oktava $\left(\mathrm{A}_{2}-\right.$ $\mathrm{a}_{4}$ ). Budući da klavir u GMV-u ima opseg od $C_{1}$ do $g_{4}$ (šest oktava i čista kvinta), možda je nastao nešto ranije (oko 1835.). Donje tipke su presvučene oblozima od bjelokosti, a gornje su načinjene od ebanovine. Oštećen je i necjelovit. Nedostaju tri noge (vjerojatno kružnog presjeka) te lira s trima pedalama. Poklopac koji se rasklapao na dva dijela odvojen je od instrumenta. Oblozi donjih tipaka su oštećeni i otpadaju, a mehanika ne radi. Žice nedostaju ili su popucale. Uz ovaj se instrument možda može povezati podatak iz Knjige ulaska od 1. veljače 1969. gdje je navedeno da je jedna varaždinska obitelj - koja je stanovala na Trgu slobode i čije prezime nije zabilježeno - darovala klavir od smeđeg drva nastao oko 1835. godine. ${ }^{46}$ U razdoblju od 1965. do 1975. klavir je bio izložen u Starome gradu na prvom katu u dvorani Bidermajer II.

\section{Povijesni klavir (GMV-KPO 54309, slika 7)}

U Starom gradu u podrumu ispod stepenica čuva se povijesni klavir. Njegov uzak i dugačak korpus izrađen je od smeđeg furniranog i politiranog drva. Okrenut je na bok. Noge su skinute, a nedostaje i lira s dvjema pedalama. Prema podacima iz muzeja dimenzije su mu 128,5 x 248 x $34 \mathrm{~cm}$ (visina bez nogu). Opseg klavijature je od $\mathrm{C}_{1}$ do $_{4}$ (šest oktava i čista kvarta). Donje tipke su pokrivene oblozima od bjelokosti, a gornje su izrađene od ebanovine. Ima drvenu konstrukciju i bečku mehaniku. Batići su pokriveni kožom. Neki nisu izvorni pa se može pretpostaviti da je bilo intervencija u mehanici. S obzirom na stanje korozije, žice su vjerojatno naknadno promijenjene. Na korpusu je vidljivo oštećenje koje je vjerojatno uzorkovano puknućem konstrukcije spoja dvije stranice. Zahvaljujući signaturi iznad klavijature „Carl Schmidt / in Pressburg“ („Carl Schmidt / u Bra-

44 Facteurs de pianos à Vienne: Lange Wilhelm, http://www.lieveverbeeck.eu/Pianos_viennois_l. htm. Pristup: 15. svibnja 2018.

45 U izvorniku: „Exp. Nro. 706. Wilhelm Lange, Fortepianomacher zu Wien, Windmühl Nr. 59, stellte ein Fortepiano von Nußbaumholz aus, und erwarb sich hierdurch den Beifall der Sachverständigen und eine ehrenvolle Erwähnung." Cit. ${ }^{* * *}$, Bericht über die zweite allgemeine österreichische Gewerbsprodukten-Ausstellung im Jahre 1839, K. K. Hof- und Staats-Aerarial Druckerei, Beč, 1840., 465.

46 Zahvaljujem Jeleni Rančić na ovim podacima. 
tislavi“) možemo odrediti ime graditelja i mjesto nastanka, a potom i dataciju. Carl (Karl) Wilhelm Schmidt (1794. - 1872.) bio je podrijetlom iz Köthen-Anhalta, a u Beč se doselio 1812. Gradnju klavira učio je u radionici Josepha Wachtla, a potom je radio kod bečkog graditelja Conrada Grafa. Od 1822. djelovao je u Bratislavi, gdje je do 1859. sagradio više od 1300 klavira s bečkom mehanikom. Taj broj svjedoči da je bio vrlo uspješan i produktivan graditelj. Ponekad se potpisivao kao „Schmidt Károly / Pozsonyban“. ${ }^{47}$

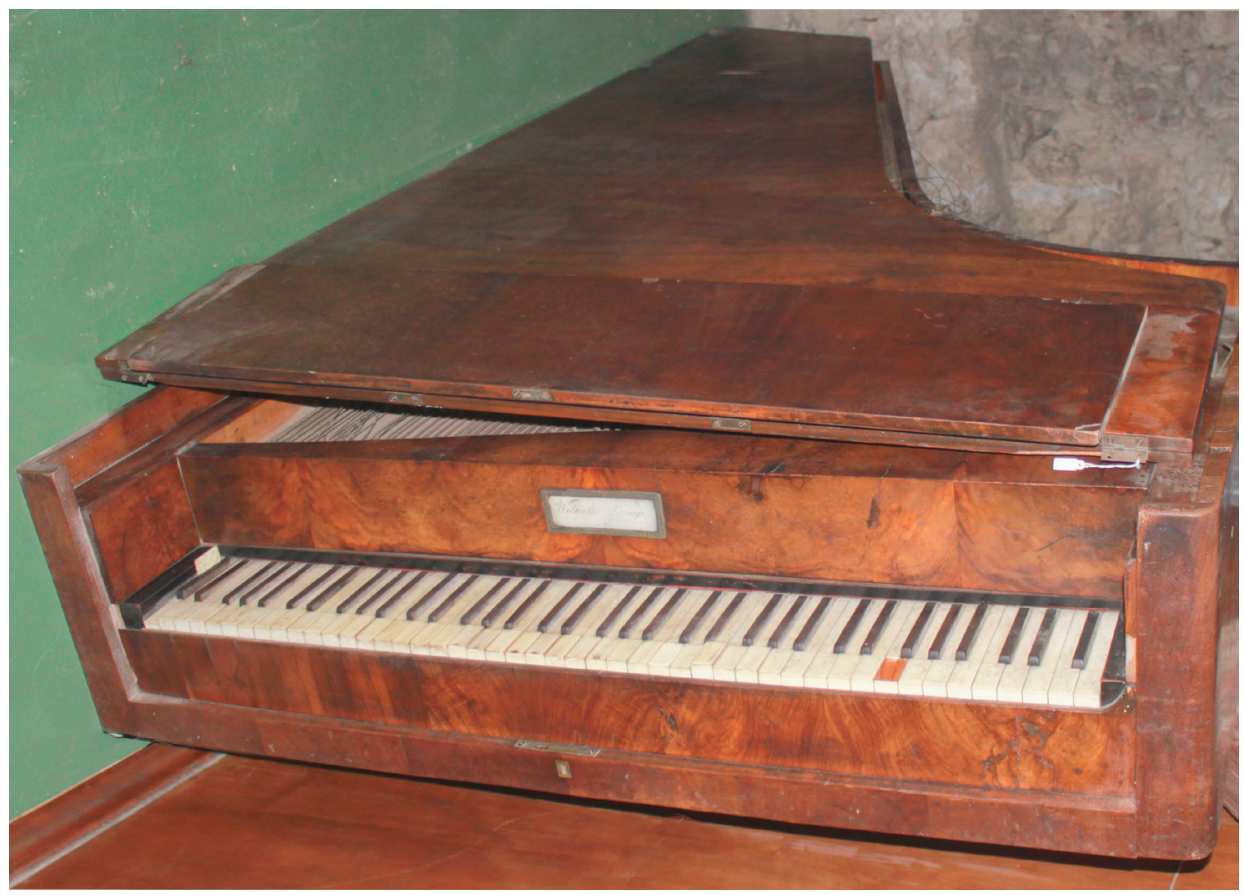

Slika 6. Povijesni klavir (GMV-KPO 54307), Wilhelm Lange, Beč, oko 1835.

Schmidt je 1854. sudjelovao i na obrtničkoj izložbi u Münchenu; pod izložbenim brojem 4732 bio je izložen njegov fortepiano. ${ }^{48}$ Istaknuo se i kao glazbeni organizator. Obogatio je glazbeni život Bratislave koncertnim gostovanjima istaknutih pijanista kao što su Sigismond Thalberg, Johann Nepomuk Hummel, Clara Wieck i Franz Listz. Tijekom 1840-ih i 1850-ih u svojoj je kući, koja je imala glazbenu

47 Pozsony je mađarski naziv za Bratislavu, iz koje je je proizašao hrvatski naziv Požun; njemački je Pressburg.

48 Usp., Katalog der Allgemeinen deutschen Industrie-Ausstellung zu München im Jahre 1854, Gemeinschaftlich gedruckt von G. Franz-W. Pössenvacher, München, 1854., 154. 


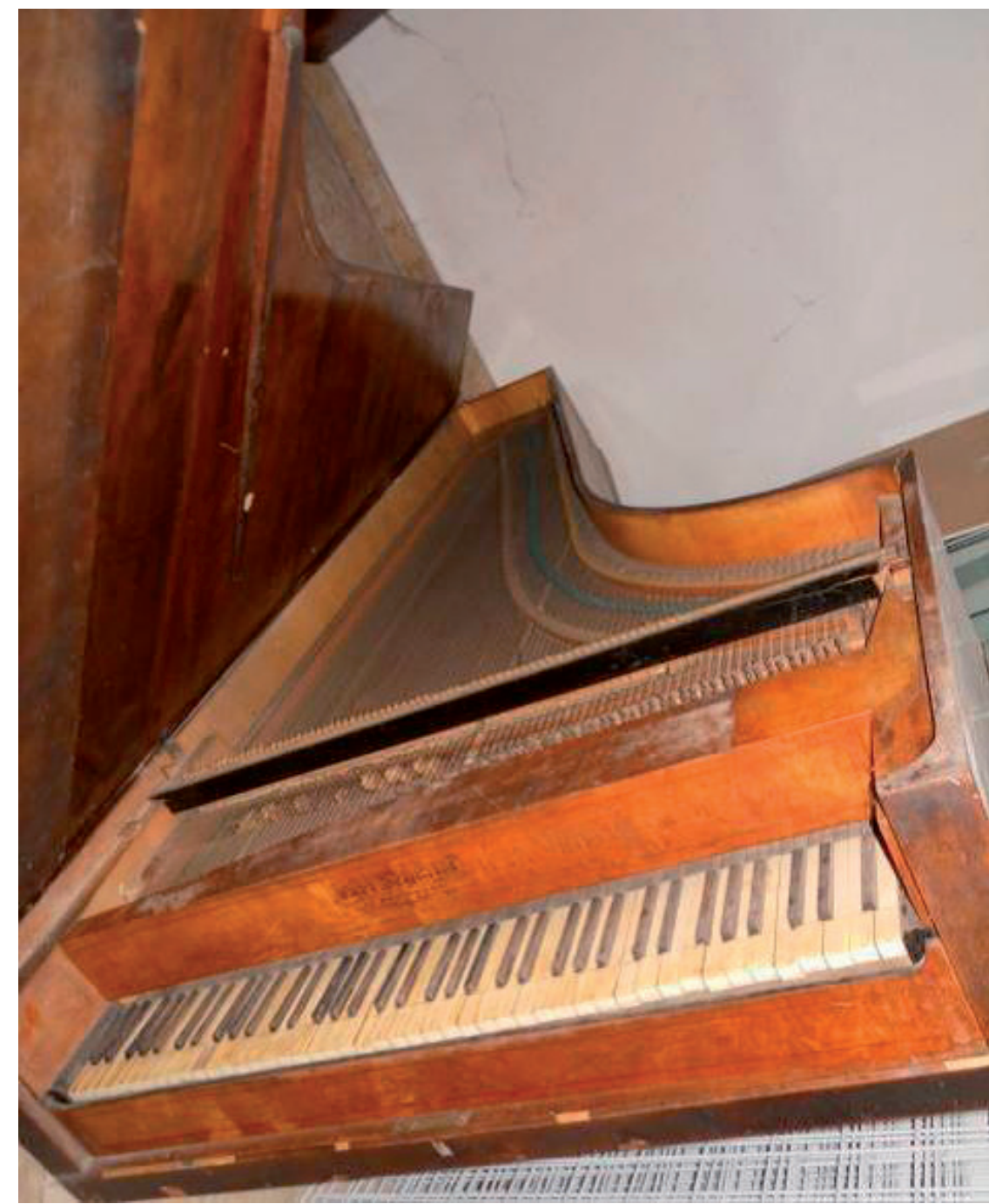

Slika 7. Povijesni klavir (GMV-KPO 54309), Carl Schmidt, Bratislava, između 1837. i 1840.

dvoranu, ugostio Antona Rubinsteina i Hansa von Bülowa. Njegov najstariji sin Carl Jakob Ludwig Schmidt (1827. - 1905.) preuzeo je radionicu 1859. Vodio ju je do zatvaranja 1877. godine. ${ }^{49}$ Jedan Schmidtov klavir, nastao u Bratislavi oko 1850.

49 Alexander RAUSCH, „Schmidt, Carl Wilhelm“, Oesterreichisches Musiklexikon Online, http://www. musiklexikon.ac.at/ml/musik_S/Schmidt_Carl.xml. Pristup: 15. svibnja 2018. 
( „Karl Schmidt / in Pressburg / Opus 1041“), čuva se u Zbirci klavira Danijela i Ljubomira Gašparovića. To je ujedno bio prvi povijesni klavir nabavljen za tu zbirku. Dimenzije su mu 131,4 x 164,7 x 90,4 cm (visina kutije 35,9 cm). Izvorno je imao drvenu konstrukciju s jednim željeznim potpornjem, a pri preradi 1910. ugrađena je željezna konstrukcija s jednom gredom; žice su ravne. Mehanika mu je bečka, a opseg klavijature od $\mathrm{C}_{1}$ do $\mathrm{a}_{4}$ (šest oktava i velika seksta). ${ }^{50}$ Schmidtov klavir u GMV-u na glasnjači ima zapisano „Opus 502“ te predstavlja raniji rad, nastao između 1837. i 1840. Muzeju ga je darovao Stjepan Đula iz Varaždina 1. veljače 1969. godine.

\section{Klavir (GMV-KPO 54332, slika 8)}

U Starom gradu u podrumu ispod stepenica čuva se i klavir u obliku krila dimenzija 149197 x $92 \mathrm{~cm}$. Stoji na tri masivne poligonalne noge koje na krajevima imaju kotačiće. Zaključan je pa se nije mogla pročitati signatura iznad klavijature, a budući da je smješten ispod stepenica nije se mogla pogledati niti unutrašnjost. Ipak, na temelju ustupljenih fotografija vidi se da se iznad klavijature, čiji je opseg sedam oktava $\left(\mathrm{A}_{2}-\mathrm{a}_{4}\right)$ nalazi grb dvoglavog orla i signatura „C. Kutschera in Wien“ ("C. Kutschera u Beču“). Na temelju toga možemo zaključiti da ga je sagradio bečki graditelj Carl (Karl) Kutschera. Prema podacima iz muzeja, u unutrašnjosti klavira još je jednom navedeno ime graditelja, kao i njegova adresa "Carl Kutschera Fortepianofabrik in Wien / Gumpendorferstr. No 91" (gradski okrug Wien VI). Iznad klavijature se uz Kutscherin potpis nalazi i popis nagrada koje je dobio za svoj rad:

1) „Auszeichnung in Jahr 1863 in Wien“ („Nagrada godine 1863. u Beču“)

2) „Preiss Medaille 1864“ („Nagrada medalja 1864.“; riječ je o velikoj srebrnoj medalji, nap. V. V.)

3) „Preiss Medaille 1868 in Linz“ („Nagrada medalja 1868. u Linzu“; riječ je o velikoj srebrnoj medalji, nap. V. V.)

Na temelju ovoga moglo bi se pretpostaviti da je klavir nastao 1868. ili neposredno nakon toga budući da su graditelji stavljali priznanja koja su već osvojili, a time i posjedovali. Ovaj klavir pripada Kutscherinu opusu 569 („,Opus no. 569“). Za usporedbu je zanimljivo spomenuti da se njegov klavir nastao u Beču nekoliko godina ranije (1864.) čuva u Pokrajinskom muzeju u Ptuju (inv. oznaka GL

${ }_{50}$ Ljubomir GAŠPAROVIĆ, Deset klavira iz zbirke Ljubomira Gašparovića, Muzej za umjetnost i obrt, Zagreb, 2012., 16-17. 
9 S) ${ }^{51}$ Kvalitetu njegova rada potvrđuje sudjelovanje na svjetskim izložbama u Beču 1873. („Weltausstellung 1873“) i 1878. („Weltausstellung 1878“), kao i prva nagrada u Teplicama 1879. („Erster Preis Teplitz / 1879“). Natpis u unutrašnjosti njegovih klavira nastalih (nakon) 1873. otkriva da je u to doba imao radionicu na adresi Zieglergasse br. 27 (gradski okrug Wien VII). Za svoj je rad 1899. dobio još jedno priznanje: status „carskog i kraljevskog dvorskog dobavljača” (njem. K. und K. Hoflieferant). Klavir u GMV-u ima konstrukciju sa željeznim okvirom s tri grede. Žice su ravne, a mehanika bečka. Oštećeno mu je kućište, ali i instrumentalni ustroj.

Darovala ga je 2008. Jagoda Kralj Novak, nacionalna prvakinja drame Hrvatskoga narodnog kazališta u Varaždinu, koja je u svojoj plodnoj glumačkoj karijeri ostvarila više od stotinu, uglavnom glavnih kazališnih uloga. U profesionalnim predstavama HNK u Varaždinu sudjeluje od 1964., a u stalni angažman ulazi 1973. Igrala je i u Hrvatskom narodnom kazalištu u Zagrebu, Gradskom dramskom kazalištu Gavella, Zagrebačkom kazalištu mladih, Maloj sceni te u Narodnom domu Maribor. Zabilježila je nastupe u televizijskim serijama Gruntovčani, Nikola Tesla, Mačak pod šljemom, Nevolje jednog Branimira, Inspektor Vinko, Ne daj se Floki, Ponos Ratkajevih, Stipe u gostima, Mamutica, Nedjeljom ujutro, subotom navečer, Da sam ja netko, Novine; televizijskim dramama Noć poslije smrti, Prijeđi rijeku ako možeš, Vježbe u Goethe Institutu, Na rubu pameti, kao i u filmovima Lov na jelene, Put u raj biznis klasom, Ne daj se Floki, Zagorka, Mezanin te Svećenikova djeca. Za svoj je rad dobila brojne nagrade i priznanja. ${ }^{52} \mathrm{U}$ razgovoru s Jagodom Kralj Novak u prosincu 2017. saznala sam da je na klaviru tijekom prva četiri razreda osnovne glazbene škole svirao njezin sin Vid Novak Kralj, magistar glazbene pedagogije i skladatelj. U HNK u Varaždinu skladao je glazbu za dječje predstave Orao, zec i divlja mačka te Tajne začarane šume, kao i za predstave Palikuće Maxa Frischa, Hotel Bellevue Ödöna von Horvátha i dr. Autor je glazbe za kabaret Singerica, čija je autorica njegova majka. Jagoda Kralj Novak uputila me i na Zdenku Jelačić Bužimski, od koje je kupila klavir. U razgovoru s njom u prosincu 2017. saznala sam da je klavir pripadao njezinoj baki Adolfini Wagner (udanoj Koch; 1860. - 1957.). Na klaviru je svirala i njezina sestra Berta Wagner, udana Mihalević, koja je bila glazbeno vrlo nadarena te je davala prve poduke iz klavira skladatelju Milku Kelemenu u Slatini (od 1921. do 1991. Podravska Slatina). Osim

51 Darja KOTER, Glasbilarstvo na Slovenskem, Založba Obzorja, Maribor, 2001., 137.

52 Marija BARIĆ, „Iz biografije Jagode Kralj Novak, nacionalne prvakinje HNK u Varaždinu“, Varaždinske vijesti, 8. svibnja 2015., http://arhiva.varazdinske-vijesti.hr/kultura/iz-biografije-jagodekralj-novak-nacionalne-prvakinje-hnk-u-varazdinu.html. Usp. i Hrvatsko narodno kazalište u Varaždinu: Jagoda Kralj Novak (nacionalna prvakinja drame), http://www.hnkvz.hr/biografija/ jagoda-kralj-novak/. Pristup: 15. svibnja 2018. 
toga, na klaviru je svirala i Adolfinina kćer Ema Koch, supruga Julija pl. Jelačića Bužimskog (sina Oskara Jelačića Bužimskog i Julije Jelačić Bužimski) te majka Zdenke Jelačić Bužimski i glumca Zvonimira Jelačića Bužimskog. Oni pripadaju desetom koljenu iz varaždinskoga ogranka plemićke grane, poteklog iz Ratkovca. ${ }^{53}$ Jagoda Kralj Novak je preko Zvonimira Jelačića Bužimskog saznala za ovaj klavir i odlučila ga otkupiti. Njegov sin je književnik Dubravko Jelačić Bužimski. Pored ovako zanimljive povijesti, za ovaj instrument možemo ustvrditi da je drugi klavir iz fundusa GMV-a koji je ranije bio u vlasništvu različitih članova plemićke obitelji Jelačić.

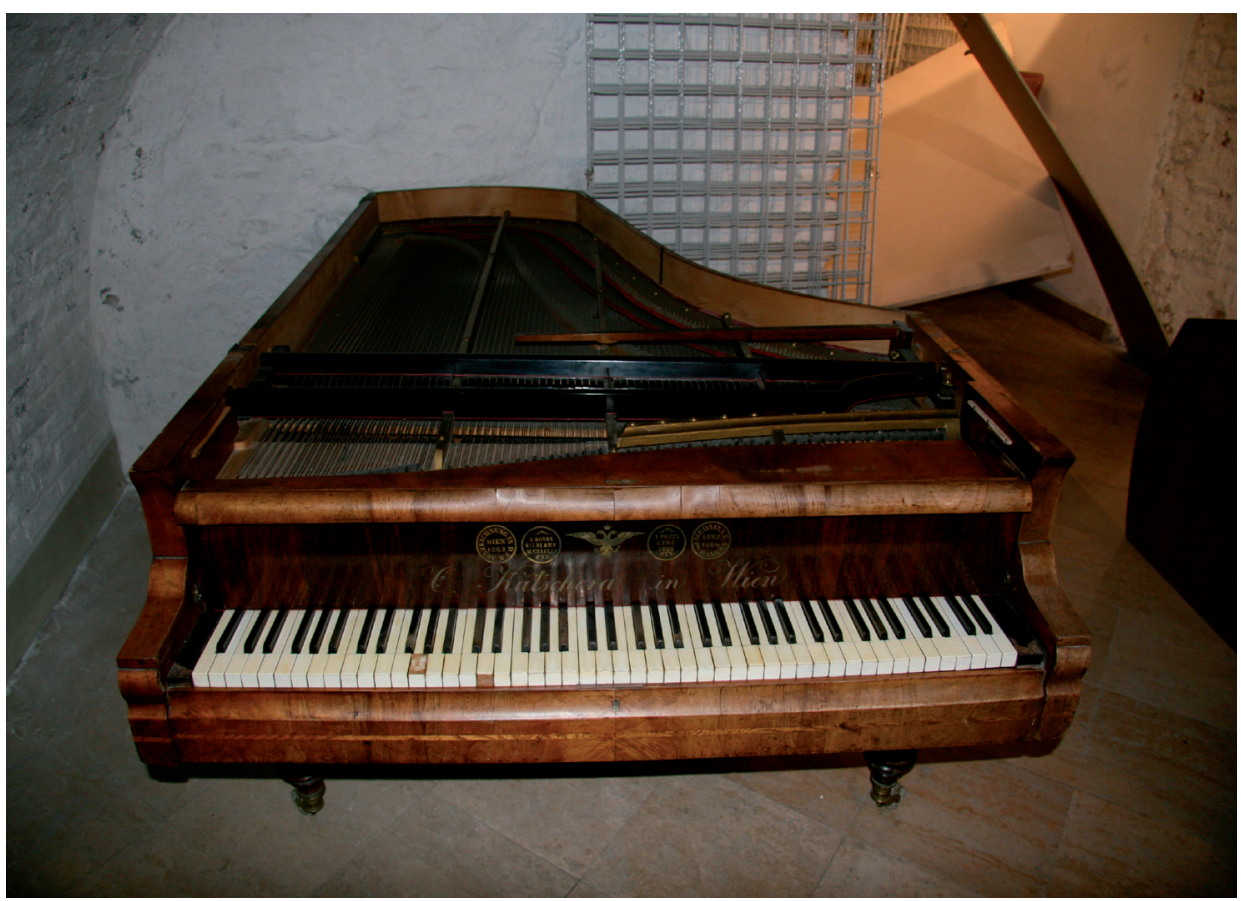

Slika 8. Klavir (GMV-KPO 54332), Carl Kutschera, Beč, 1868.

ili neposredno nakon toga.

\section{Klavir (GMV-KPO 2823, slika 9)}

U Starom gradu u tehničkom depou za vitrine i stalke (kraj kuhinje) čuva se klavir koji nosi signaturu „J. Fritz \& Sohn / in Wien“ („J. Fritz i sin / u Beču“). Is-

53 Ratkovec je općina u sastavu Grada Zlatara u Krapinsko-zagorskoj županiji. 
pod žica je natpis s detaljima o adresi na kojoj je djelovao i broju opusa ovog klavira: „J. Fritz \& Sohn / in Wien / Mariahilferstrasse / No 47 / Opus No 1674“. Na temelju toga bi se moglo povezati da je rad Josefa Kaspara Fritza (1808. - 1877.), sina Johanna Petera Fritza (? - oko 1834.), jednog od najvažnijih bečkih graditelja klavira u prvoj trećini 19. stoljeća. ${ }^{54} \mathrm{O}$ životu Johanna Petera Fritza malo je poznato, ali mnogi segmenti njegova rada upućuju da je gradnju klavira učio u radionici Antona Waltera u Beču. Njegova radionica, koju je osnovao 1806., djelovala je dulje od jednog stoljeća. Klaviri Johanna Petera Fritza bili su poznati po profinjenom zvuku, skladnim proporcijama i pomno obrađenom korpusu. Johann Peter Fritz se, zajedno s Conradom Grafom, Antonom Walterom i Johannom Andreasom Streicherom, ubraja među najčešće kopirane graditelje pri izradi replika instrumenata iz prve polovice 19. stoljeća.

Josef Kaspar Fritz vlastitu radionicu je otvorio 1837., a od 1867. radio je sa svojim sinom..$^{55}$ Ispod žica je i natpis da je sudjelovao na izložbi 1873. pa možemo odrediti da je klavir nastao 1873. ili neposredno nakon toga. Njegovi klaviri nastali narednih godina iznad signature "J. Fritz \& Sohn / Wien“ imaju natpis "Silber \& Gold-Medaille 1880“ („,srebrna i zlatna medalja 1880.“), a s lijeve i desne strane natpise u kružnici (očito napravljene po uzoru na dobivene medalje) „Preis-Medaille“ („nagrada medalja“) i „Paris 1878“. Klavijatura ovog klavira ima opseg od sedam oktava $\left(A_{2}-a_{4}\right)$. Stalak za note je izrezbaren vegetabilnim uzorcima i lirom u sredini. Lijevo i desno od stalka za note su pomična postolja, također izrezbarena vegetabilnim uzorcima. Zbog muzejske građe koja je bila poslagana ispred njega, prilikom posjeta GMV-u u studenom 2016. ovaj se klavir nije moglo detaljnije pogledati. Prema ustupljenim fotografijama i podacima iz muzeja, instrument je relativno dobro očuvan i cjelovit, osim što je lira s dvije pedale odvojena od njega. Jedan klavir Josefa Fritza, nastao oko 1860., čuva se u Pokrajinskom muzeju u Ptuju (inv. oznaka GL 7 S). ${ }^{56}$

Klavir u GMV-u darovala je Božica Kričevcov iz Varaždina 20. kolovoza 1975. U razgovoru s njezinom kćeri Natašom Maričić u prosincu 2016. saznala sam da je obitelj Kričevcov klavir nabavila 1970. od obitelji Mihalić iz Varaždina. Nataša Maričić na tom je klaviru vježbala za vrijeme osnovne glazbene škole. Za vježbanje većih i zahtjevnijih djela glazbene literature u srednjoj glazbenoj školi ovaj instrument više nije bio prikladan (ponajprije zbog dotrajale mehanike) pa su joj roditelji nabavili novi. Nataša Maričić diplomirala je muzikologiju na Odsjeku za

\footnotetext{
54 D. KOTER, n. dj., 137.

55 Facteurs de pianos à Vienne: Fritz Josef Kaspar, http://www.lieveverbeeck.eu/Pianos_viennois_f. htm. Pristup: 15. svibnja 2018.

56 D. KOTER, n. dj., 137.
} 
muzikologiju Filozofskog fakulteta Sveučilišta u Ljubljani. Zaposlena je u Glazbenoj školi Varaždin gdje predaje povijest glazbe, glazbene oblike, glazbenu literaturu i glazbeni folklor. Nataša Maričić uputila me i na Zvjezdanu Horvat, kći Stjepana Mihalića, od koje sam saznala da su na klaviru u dječjoj i mladenačkoj dobi svirali ona i njezin stariji brat Velimir Mihalić. Oboje su pohađali glazbenu školu. Zvjezdana Horvat završila je osnovnu, a Velimir Mihalić i srednju glazbenu školu u Varaždinu. Studirao je na Pedagoškoj akademiji u Čakovcu te je predavao glazbenu kulturu u osnovnim školama u Bednji i Vrbnu (općina Bednja). Zvjezdana Horvat je po zanimanju diplomirana pravnica te radi u varaždinskoj Gradskoj vijećnici, u Upravnom odjelu za poslove gradskog vijeća, mjesnu samoupravu i opće poslove. Nakon što su Mihalićevi prodali klavir obitelji Kričevcov, sebi su kupili novi.

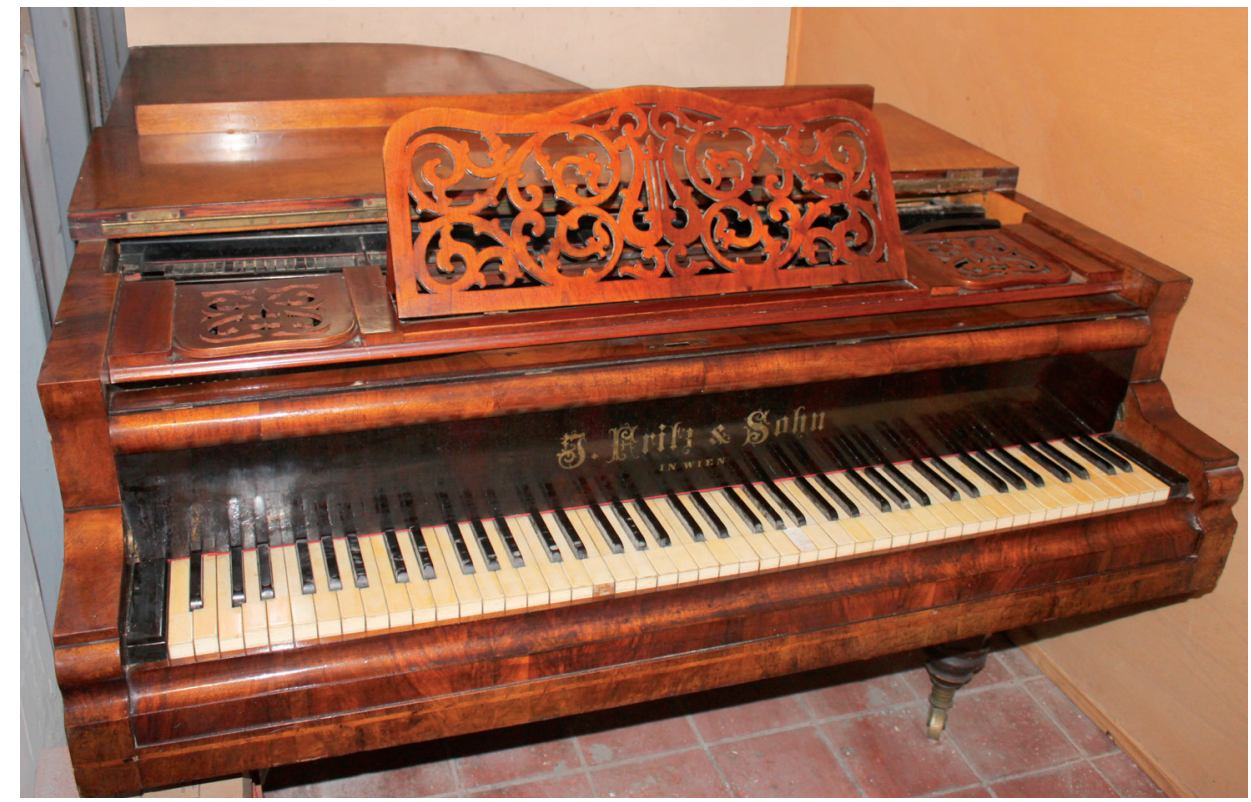

Slika 9. Klavir (GMV-KPO 2823), Josef Kaspar Fritz, Beč, 1873. ili neposredno nakon toga.

\section{Klavir (GMV-KPO 85785, slika 10)}

U prizemlju palače Herzer čuva se klavir dimenzija 145 × 200 x $93 \mathrm{~cm}$. Riječ je o jednoj od najnovijih akvizicija koja je u GMV pristigla 2015. Korpus u 
obliku krila izrađen je od smrekovine te obložen furnirom od palisandra. Ima konstrukciju sa željeznim okvirom s tri grede. Žice su ravne, a mehanika bečka. Klavijatura ima opseg od sedam oktava $\left(\mathrm{A}_{2}-\mathrm{a}_{4}\right)$. Donje tipke su izrađene od bjelokosti, a gornje od ebanovine. Klavir stoji na tri osmerostrane noge koje su gore šire, pri dnu se sužavaju, a na završecima imaju kotačiće. Odlikuje se elegantnim izgledom i skladnim linijama, a naročito je zanimljiv mrežasto izrezbaren stalak za note. Izvana je relativno dobro očuvan (oblozi nekih gornjih tipaka su otpali, furnir je malo oštećen), ali mu mehanika ne radi.

Na crnoj podlozi iznad klavijature uz lik dvoglavog orla ispisana je signatura „J. Promberger \& Sohn / K. K. Hof-Forte Piano Fabrik in Wien“ („J. Promberger i sin / carska i kraljevska dvorska tvornica klavira u Beču“). U unutrašnjosti klavira je natpis „J. Promberger \& Sohn / Kaiserl. König. Hof Piano Forte Fabrik / Wien / Josefstadt, Wickenburggasse No 17“ (gradski okrug Wien VIII). Johann Promberger stariji (1779. - 1834.) bio je podrijetlom iz južnog Tirola. U Beču je najprije radio kao pomoćnik u radionici Matthiasa Müllera starijeg (1770. - 1844.), jednog od najinovativnijih bečkih graditelja svoga vremena, izumitelja jednog od najranijih tipova uspravnog klavira, tzv. Ditanaklasis ili Dittaléloclange (1800.). Nakon što se 1810. oženio Annom Wissgill Schweighofer, udovicom Michaela Schweighofera, 1811. nastavio je voditi njegovu radionicu pod imenom Schweighofer und Promberger. Bio je očuh Johanna Michaela Schweighofera, čiji su sinovi Carl i Johann sagradili klavir opisan nakon ovog (GMV-KPO 52991). Njegov sin Johann Promberger mlađi (1810. - 1889.) bio je pijanist, skladatelj, glazbeni pedagog i graditelj klavira. Gradnju klavira učio je od oca te kolege u njegovoj radionici Josepha Franza Riesa (1792. - 1861.). Klavir je učio kod Carla Czernija (1791. - 1857.) i Carla Marije von Bockleta (1801. - 1881.), a kompoziciju kod Ignaza Seyfrieda (1776. - 1841.). Već je kao 12-godišnjak održao zapažene koncerte. Od 1843. s velikim je uspjehom djelovao u Sankt Peterburgu kao pijanist, orguljaš, skladatelj, glazbeni kritičar i učitelj klavira. ${ }^{57}$ Johann Strauß sin posvetio mu je 1857. valcer Telegrafishe Depeschen (Telegrafska otprema), op. 195. Johann Promberger mlađi se u Beč vratio 1870. ili nedugo nakon toga. S obzirom na njegovu dob, možemo pretpostaviti da je ovaj klavir nastao oko 1875 . U radionici Prombergerovih zabilježen je kao „Opus 1607“.

Klavir je kupio Franjo Košćec (1882. - 1986.) supruzi Ivki Košćec (rođ. Darány) kao vjenčani dar 31. srpnja 1918. Franjo Košćec bio je istaknuti zoolog-entomolog, florist, izumitelj, pedagog i muzealac. Tijekom više desetljeća terenskog rada

57 Uwe HARTEN, „Promberger, Familie“, Oesterreichisches Musiklexikon Online, http://www. musiklexikon.ac.at/ml/musik_P/Promberger_Familie.xml. Pristup: 15. svibnja 2018. 
prikupio je na desetke tisuća entomološkog i drugog biološkog materijala, od kojih je do danas ostalo sačuvano oko 35000 primjeraka. Materijale je uglavnom sakupljao u varaždinskoj okolici, na livadama i šumama oko Drave te na dijelovima Ivančice i Ravne gore, objedinivši ga u zbirke koje su danas važan dokument o fauni sjeverozapadne Hrvatske prve polovice 20. stoljeća. Upravo su te zbirke bile temelj za osnivanje Entomološkog odjela Gradskog muzeja Varaždin, otvorenog u palači Herzer 1954. Franjo Košćec bio je autor prvoga stalnoga postava i prvi kustos odjela do 1962., kada ga je naslijedila kći Ružica Košćec (1920. 2002.), profesorica biologije koja je tamo radila do umirovljenja 1980. Cjelokupnu prirodoslovnu ostavštinu s entomološkim zbirkama, herbarijem, instrumentarijem, knjižnicom, rukopisima, crtežima i nastavnim pomagalima, Franjo Košćec darovao je Gradskom muzeju Varaždin 1959. Njegova zbirka ubraja se među najvrjednije entomološke zbirke u Hrvatskoj. Dio građe izložen je u stalnom postavu Entomološkoga odjela GMV-a pod naslovom Svijet kukaca. Stalni postav je 2014. obilježio 60 godina djelovanja, tijekom kojih je doživio i nekoliko obnova. ${ }^{58}$

Klavir je naslijedila njegova najmlađa kći Đurđa (Duda) Košćec (udana Kovačić), koja ga je 1972. prodala Milki i Zoranu Jakopoviću. Obitelj Jakopović ga je u ožujku 2009. darovala Galerijskom centru Varaždin, koji ga je u veljači 2015. darovao Gradskom muzeju Varaždin. Prema sjećanju potomaka Franje Košćeca, uz taj su se klavir u dnevnom boravku u stanu u Draškovićevoj ulici od 1920 -ih pa do sredine 1940-ih priređivala obiteljska druženja, a posebno je dojmljiv bio Božić, kada se uz tradicionalnu božićnu pjesmu Narodil nam se kralj nebeski s nestrpljenjem iščekivalo odmatanje božićnih darova, pripremljenih upravo na tom klaviru. ${ }^{59}$ Ovaj klavir dopunjuje impresivnu profesionalnu biografiju Franje Košćeca jer svjedoči o njemu kao o brižnom obiteljskom čovjeku, dodajući mu i vrijednu ljudsku dimenziju. Klavir je obogatio i Ostavštinu Franje Košćeca, zbirku Entomološkog odjela GMV-a koja je osnovana njemu u spomen. Prema vrsti građe (glazbeni instrument) klavir je dodijeljen Glazbenoj zbirci Kulturnopovijesnog odjela.

58 Antica BREGOVIĆ, „Franjo Košćec: osnivač Entomološkog odjela Gradskog muzeja Varaždin“, Muzejski vjesnik: glasilo muzeja sjeverozapadne Hrvatske, 4, Varaždin, 1982, 77-79.

59 Marija BARIĆ, „Klavir iz obitelji prof. Franje Košćeca doniran GMV-u“, Varaždinske vijesti, 24. ožujka 2015., http://arhiva.varazdinske-vijesti.hr/kultura/klavir-iz-obitelji-prof-franje-koscecadoniran-gmv-u. html. Pristup: 15. svibnja 2018. 


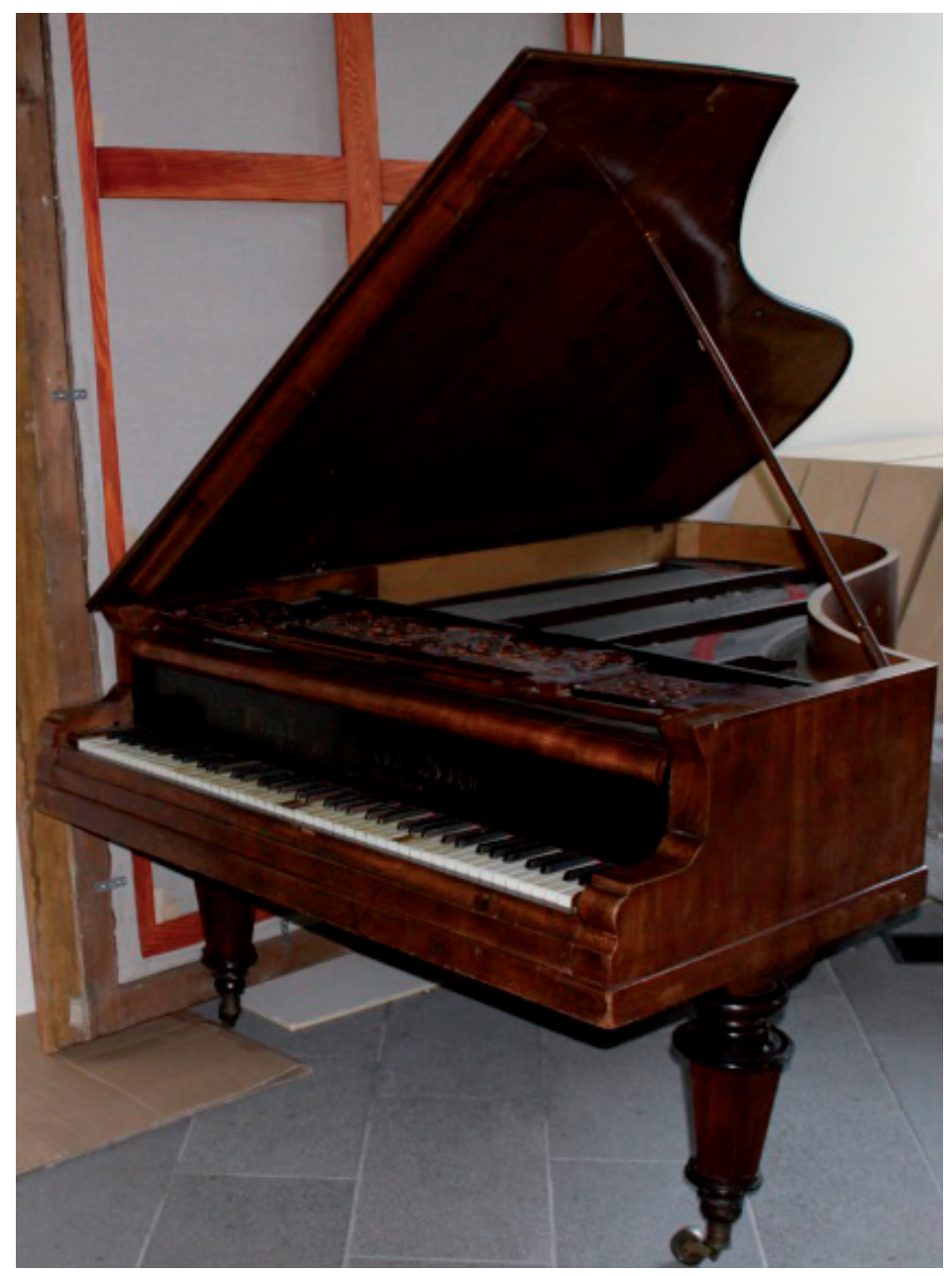

Slika 10. Klavir (GMV-KPO 85785), Johann Promberger mlađi, Beč, oko 1875.

\section{Klavir (GMV-KPO 52991, slika 11)}

Dimenzije ovog kratkog koncertnog klavira su 142 x 170 x 100 cm. Korpus je izrađen od smrekovine i obložen furnirom od orahovine. U njemu je smješten željezni okvir nalik na položenu harfu. Stoji na tri osmerostrane noge koje su gore šire, pri dnu se sužavaju, a na završetcima imaju kotačiće. Poklopac nad klavijaturom nekoć se mogao zaključati jer ima ključanicu. Klavijatura ima op- 
seg od sedam oktava $\left(A_{2}-a_{4}\right)$. Donje tipke su bijele boje, a gornje crne. Dvije pedale smještene su na centralno ovješenoj liri (lijeva piano i desna forte). Stalak za note $\mathrm{u}$ obliku pravokutnika izrezbaren je horizontalnim prečkama, a u sredini u ovalu je shematski prikaz sunca i sunčevih zraka. S njegove lijeve i desne strane su okrugla pomična postolja. Na crnoj obojenoj plohi iznad klavijature nalazi se signatura "Schweighofer" i grb dvoglavog orla, a u unutrašnjosti "J. M. Schweighofer / Söhne Wien / gegründet 1792“ („,Sinovi J. M. Schweighofera Beč / utemeljeno 1792.“), na temelju čega saznajemo da su ga izgradili sinovi Johanna Michaela Schweighofera (1806. - 1852.). Prvi graditelj klavira u ovoj obitelji bio je njegov otac Michael Schweighofer (1771. - 1809.), podrijetlom iz Bavarske, koji je 1792. otvorio radionicu u Beču, a 1801. dobio građansko pravo. Michaelova udovica Anna Wissgill Schweighofer (1780. - 1822.) udala se 1810. za graditelja klavira Johanna Prombergera starijeg (1779. - 1834.), također. ${ }^{60}$ Kao što je već spomenuto, njegov sin Johann Promberger mlađi sagradio je prethodno opisani klavir (GMV-KPO 85785).

Johann Michael Schweighofer gradnju klavira učio je kod svog očuha u Beču, a kasnije se usavršavao u Njemačkoj, Francuskoj i Engleskoj. Po povratku u Beč 1832. otvorio je vlastitu radionicu u gradskom okrugu Wein IX. Četiri godine kasnije preselio se u bečko predgrađe Laimgrube, a od 1845. djelovao je u okrugu Wien V. Iste je godine na izložbi u Beču osvojio zlatnu medalju ${ }^{61}$ Njegovi klaviri čuvaju se, među ostalim, u Zbirci glazbenih instrumenata Njemačkog nacionalnog muzeja u Nürnbergu (oko 1835.), ${ }^{62}$ Pokrajinskom muzeju u Ptuju (oko 1835.), ${ }^{63}$ Zbirci povijesnih glazbenih instrumenata Muzeja povijesti umjetnosti u Beču (oko 1845.), ${ }^{64}$ Zbirci glazbenih instrumenata Švedskog muzeja izvedbenih umjetnosti u Stockholmu (oko 1846.) ${ }^{65}$ te u Univerzalnom muzeju Joanneum u Grazu (između 1840. i 1850.). ${ }^{66}$ Nakon smrti Johanna Michaela Schweighofera 1852. radionicu je preuzela njegova udovica Franziska Schweigerhofer. Njihov sin Carl

60 O graditeljima klavira iz obitelji Promberger više će riječi biti kod sljedećeg klavira (GMV-KPO 85785).

61 Christian FASTL, „Schweighofer, Familie“, Oesterreichisches Musiklexikon Online, http://www. musiklexikon.ac.at/ml/musik_S/Schweighofer_Familie.xml. Pristup: 15. svibnja 2018.

62 Martha NOVAK CLINKSCALE, Makers of the Piano 1820-1860, Oxford University Press, New York, 1999., sv. 2, 337.

63 D. KOTER, n. dj., 136.

64 Clinkscale Online: A Comprehensive Database of Early Pianos, 1700-1860: CEP-3189, http://early pianos.org/. Pristup: 15. svibnja 2018.

65 Scenkonstmuseet, http://instrument.musikverket.se/samlingar/detalj.php?l=sv\&iid=246\&v=2008-01-28\%20 09:36:56\&str=Schweighofer. Pristup: 15. svibnja 2018.

66 Clinkscale Online: A Comprehensive Database of Early Pianos, 1700-1860: CEP-3192, http://early pianos.org/. Pristup: 15. svibnja 2018. 
Schweighofer (1839. - 1905.) nastavio je roditeljskim stopama te je za svoje klavire osvojio nagradu na Svjetskoj izložbi Parizu 1867. Naredne godine u poslu mu se pridružio mlađi brat Johann Schweighofer (1840. - 1889.) pa je od tada radionica nosila ime J. M. Schweighofer Söhne. Godinu kasnije (1869.) dodijeljen im je status "carskih i kraljevskih dvorskih graditelja klavira" (njem. K. K. Hof-Klavier-Fabrikanten), a 1873. osvojili su počasnu diplomu na Svjetskoj izložbi u Beču. ${ }^{67}$ Tema ove izložbe bila je Kultura i obrazovanje (njem. Kultur und Erziehung), a otvorio ju je car Franjo Josip I. Na izložbi je sudjelovalo 35 zemalja i 53000 izlagača, a posjetilo ju je više od sedam milijuna posjetitelja. Klaviri iz radionice braće Schweighofer bili su cijenjeni zbog visoke kvalitete, a godišnje ih se proizvodilo oko dvije stotine (uključujući i pijanina).

Kod klavira u GMV-u podaci o nagradama zabilježeni su na željeznom okviru u unutrašnjosti klavira s lijeva na desno kako slijedi:

1) „Goldene Medaille Wien 1845.“ („Zlatna medalja Beč 1845.“)

2) „Erster Preis München 1854.“ („Prva nagrada München 1854.“)

3) „Silberne Medaille Paris 1867.“ (,Srebrna medalja Pariz 1867.“)

4) „Ehren-Diplom höchste Auszeichnung Weltausstellung Wien 1873.“ („Počasna diploma najviša nagrada Svjetska izložba Beč 1873.“)

Što se pak tiče statusa braće Schweighofer, on je u unutrašnjosti ovog klavira zabilježen kao „K. u. K. Hof u. Kammer-Clavier-Fabrinakanten / goldenes Verdienst Kreuz mit Krone“ (,carski i kraljevski komorni graditelji klavira / zlatni križ za zasluge s kunom““68). Zahvaljujući ovim detaljima te karakteristikama klavira, možemo odrediti da je nastao krajem 1880-ih. Predstavlja instrument vrhunske kvalitete. Dobro je očuvan, ali je jako neugođen. Smješten je u podrumu ispod stepenica u Starom gradu.

67 Howard SCHOTT, Anne BEETEM ACKER, "Schweighofer", Oxford Music Online. Grove Music Online, http://www.oxfordmusiconline.com/grovemusic/view/10.1093/gmo/9781561592630.001.0001/ omo-9781561592630-e-4002294747. Pristup: 15. svibnja 2018.

68 Ovdje taj križ nije prikazan, ali inače je bio izrađen od emajliranog zlata ili pozlaćene bronce. U sredini križa, u ukrasnom prstenu, na bijelom emajliranom medaljonu bila su napisana slova „FJ“ (prema caru Franji Josipu I). Iznad križa bila je austrijska carska kruna. 


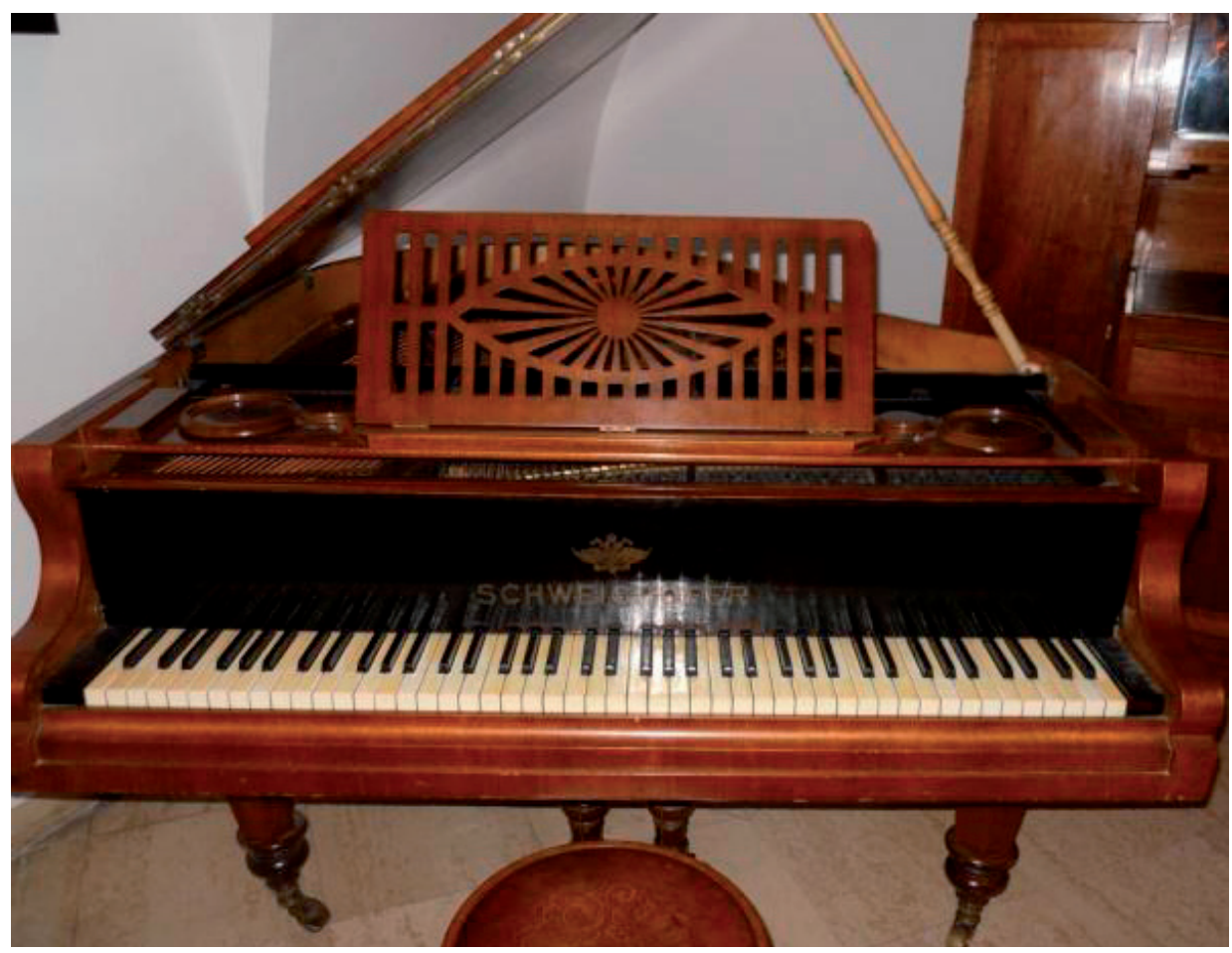

Slika 11. Klavir (GMV-KPO 52991), Carl i Johann Schweighofer, Beč, kraj 1880-ih.

\section{Pozitiv (GMV-KPO 2734, slike 12 i 13)}

Pozitiv je pripadao inventaru dvorca Borl na Dravi u Sloveniji. U Gradski muzej Varaždin dospio je 1937. iz dvorca Opeka ${ }^{69}$ u općini Vinica kao otkup od grofa Josipa Bombellesa (1894. - 1942.). ${ }^{70}$ Po vanjštini i strukturi kućišta ovaj pozitiv tipološki pripada renesansno-baroknom ormaru s naglašenim završnim vijencem, koji izbija $13 \mathrm{~cm}$ preko rubova prednje i bočnih strana kućišta. Ovakav tip kućišta, u različitim varijantama, bio je prisutan u čitavom 17. i početkom

69 O dvorcu i perivoju u Opeki usp. M. OBAD ŠĆITAROCI, $n$. dj., 200-207.

${ }_{70}$ U blagajničkoj knjizi Varaždinskog muzealnog društva zabilježena je 16. rujna 1937. isplata za orgulje grofu Bombellesu u iznosu od 7000 dinara. Kočijašu je kao nagrada za njihov dovoz plaćeno 5 dinara. Tri dana kasnije (19. rujna 1937.) težacima je za prijenos orgulja isplaćeno 10 dinara, a potom 21. rujna još 20 dinara. Za popravak orgulja je orguljaru Gradiščaju 25. rujna plaćeno 80 dinara. Zahvaljujem Jeleni Rančić na ovim podacima. 
18. stoljeća, a kod malih orgulja zadržao se i kasnije. Pozitiv u GMV-u ima dva glavna dijela: donji dio (bazu) i gornji dio kućišta koje razdvaja uski rubni vijenac. Baza instrumenta je, zbog prostorne zapremine koja je potrebna za mjehove, šira i dublja od gornjeg dijela. Ukupna visina kućišta iznosi 212,5 cm. Dimenzije donjeg dijela su 81 × 109 × 91,5 cm; dimenzije gornjeg dijela su 131,5 x 107 × 68,5 $\mathrm{cm} .{ }^{71}$ Mjehovi se pokreću povlačenjem remena kroz otvore na lijevom boku kućišta. U gornjem dijelu instrumenta razlikuju se dva dijela, koja su vidljiva i na vanjskoj strani kućišta. Najdonji dio zaprema prostor značnica, sredinu ormar s prospektom, sviraonikom i sviralama, a završni dio karakterizira vijenac poduprt frizom koji je ukrašen geometrijskim oblicima. Prostor zračnica ispunjen je nizom izbrazdanih letvica, koje oponašaju slijepe ladice. Iza stražnje strane pozitiva nalaze se otvori zračnica s dva poklopca, a još dublje unutra su kancele u koje se pušta zrak pomicanjem željeznih ručica za otvaranje registara. Otvaranja registara temelji se na sustavu kliznih pomicaljki. ${ }^{72}$

Središnji i prostorno najveći dio zaprema ormar sa sviralama na čijoj se prednjoj strani nalazi ukusno ukrašeni prospekt. Njega čine piramidalno složene svirale, dok neispunjene dijelove okvira popunjavaju izrezbarene dvobojne akantusove zavjese zlatnožute i tamnoplave boje (što je postao zaštitni znak Varaždinskih baroknih večeri). Bočne strane ormara izvučene su do prednjeg zida kućišta, tvoreći tako bijelo obojenu nišu koja se zatvara dvokrilnim vratima. Unutrašnje plohe vratnica oslikane su prizorima Navještenja: na lijevom je krilu anđeo, a na desnom Marija. Tipke se odlikuju pomnom izradom. Donje tipke (2,3 ili 2,4 x 9,5 $\mathrm{cm})$ obložene su bjelokošću, a na rubovima su blago zaobljene. Gornje tipke (1,3 x 5,9 cm) izrađene su od ebanovine i imaju dosta oštro rezane bridove. Klavijatura je dugačka $65 \mathrm{~cm}$ te ima opseg od C/E do $\mathrm{c}_{3}$; tri oktave i jednu skraćenu. Prva tipka koja izgleda kao E daje ton C (otuda ozaka C/E), tonovi D i E smješteni su na crnim tipkama. Tipke najdublje oktave nemaju kromatskih tonova (osim tona b). Od malog c klavijatura ide punim kromatskim nizom do $c_{3}$. Ovakav raspored proizlazi iz orguljaške prakse 17. stoljeća, a u Hrvatskoj se zadržao sve do 19. stoljeća. ${ }^{73}$ Kućište je izvana crno obojeno. Pozitiv ima pet registara sljedeće dispozicije: Copula maior 8' (velika poklopljenica), Portun 4' (otvorena flauta), Quinta 22/3' (u prospektu), Principal 2', Octav 1'.74

\footnotetext{
71 Visina $x$ širina $x$ duljina.

72 Ladislav ŠABAN, „Dva pozitiva u Muzeju grada Varaždina“, Godišnjak Gradskog muzeja Varaždin, 4, Varaždin, 1970, 106. Usp. i Ladislav ŠABAN, „Varaždin muzej: pozitiv iz Borla“, Digitalna zbirka Hrvatske akademije znanosti i umjetnosti, http://dizbi.hazu.hr/object/19962. Pristup: 15. svibnja 2018.

73 L. ŠABAN, „Dva pozitiva u Muzeju grada Varaždina“, 107.

74 Isto, 108 i 114
} 
Na unutarnjoj strani gornje pločice mijeha na pergameni $(34 \times 22 \mathrm{~cm})$ nalazi se graditeljev autograf, koji osim njegova imena otkriva i vrijeme nastanka pozitiva. Natpis je pronađen tijekom restauracije u Umjetničkoj radionici Heferer 2007.

„Den 1668-sten Jahr ist das Werk gmacht worden in Lebenszeit des Hochund Wohlgeborenen Herrn Georg Friedrich Sauer, Freiherr zu Kosiak, Sternau, Wöllau, Ankenstein (Borl), Lilienberg und Dornau, Erblandvorschneider in Krain und der Windischen Mark, Kö. Kai. Maj. Kämmerer, und einer Löblichen Laa. [Landtags?, Landstände?] in Steiermark, Obrist Proviant Meister der Windischen und Petrinischen Grenze, dessen Frau Gemahlin Ihre Gnaden Frau Maria Barbara, Frau Sauerin Freiin, eine geborene Gräfin von Trautmansdorf. Folgt die adlige Jugend, erstlich Fräuelin Maria Cecilia, Fräuelin Maria Francisca, Fräuelin Clara, Herr Leopold Carl, Herr Ferdinand, Herr Georg Sigmund. Nach dem folgen die Offiziere, Johann Lucas Strasser Verwalter akhier, Georg Minis Sekretari alhier, Johann Lorenz Söllau Organist alhier, Niclas Kagantsch Kellerer alhier, Peter Leidthart Tischler alhier, welcher auch das Werk hat vollenden geholfen.

Ankenstein (d. h. Borl) den 21. März Anno ut supra

Der das Werk hat gemacht,

Sein Parschon [Person] ist alhier nicht verachtet,

In Schweizland ist er geboren,

Seine Name wird herunten auserkoren.

Rudolf Rapoldt, Orgel Macher"

\section{U prijevodu na hrvatski to znači:}

„1668. godine je ovo djelo napravljeno, u vrijeme kad je živio visokog i dobrog roda gospodin Georg Friedrich Sauer, barun od Kosiaka, Sternaua, Wöllaua, Ankensteina (Borla), Lilienberga i Dornaua, uručitelj nasljedne zemlje u Kraini i Vindijskoj grofoviji, komornik kraljevskog i carskog veličanstva i slavnog zemaljskog sabora u Štajerskoj, pukovnik majstor za opskrbljivanje namirnicama vindijske i petrinjske granice, čija je supruga milostiva gospođa Maria Barbara, rođena grofica od Trautmansdorfa. Slijedi plemenita mladež, najprije gospođica Maria Cecilia, gospođica Maria Francisca, gospođica Clara, gospodin Leopold Carl, gospodin Ferdinand, gospodin Georg Sigmund. Zatim slijede časnici Johann Lucas Strasser, upravitelj ovdje, Georg Minis, sekretar ovdje, Johann Lorenz Söllau, orguljaš ovdje, Niclas Kagantsch, podrumar ovdje, Peter Leidthart, stolar ovdje, koji je također pomogao da se ovaj rad ovdje i dovrši,

Ankenstein (tj. Borl) 21. ožujka Anno ut supra 
Onaj koji je ovo djelo napravio

njegova se osoba ovdje ne prezire,

u Schweizlandu on je rođen

njegovo se ime ovdje dolje odabrati može.

Rudolf Rapoldt, graditelj orgulja“75

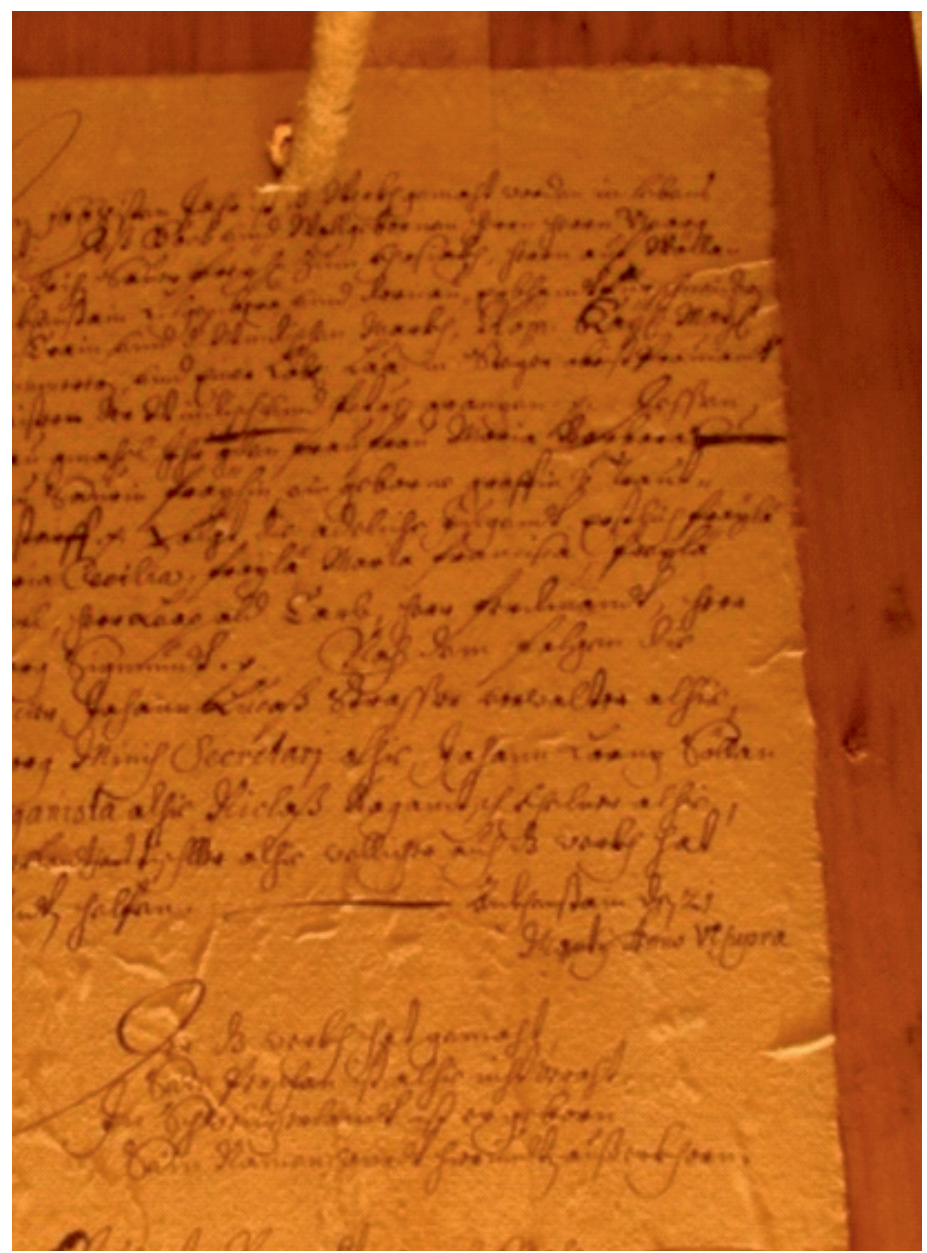

Slika 12. Autograf Rudolfa Rapoldta pronađen prilikom restauracije pozitiva 2007.

75 Natpis je pročitala Dorotea Baričević, a s njemačkog na hrvatski prevela Mirna Rukavina-Bakšaj. Cit. Miroslav KLEMM, Zdenko KUŠĆER, Pozitiv Rudolfa Rapoldta u Gradskom muzeju Varaždin 16682007., Gradski muzej Varaždin, Varaždin, 2007., 6-7. 
Pozitiv je, dakle, 1668. sagradio štajerski majstor Rudolf Rapoldt (Rappoldt, Rappolt), rodom iz Švicarske („Schweizland“), koji je od 1664. do 1688. djelovao u austrijskom gradu Bruck an der Mur. ${ }^{76}$ Varaždinski pozitiv jedini je sačuvani Rapoldtov instrument s vlastoručnim zapisom graditelja, koji posjeduje više od $80 \%$ izvornog foničkog materijala. To ga čini najočuvanijim u odnosu na još tri instrumenta u Štajerskoj koja se mogu pripisati ovom graditelju: pozitiv za crkvu sv. Nikole u Brucku (ujedno i najstariji pozitiv u tom gradu), pozitiv u župnoj crkvi u Sankt Peter-Freiensteinu te pozitiv u crkvi sv. Joakima i Ane u Heiliger Bergu u Bärnbachu. Svi su instrumenti tipološki jednako koncipirani. To su male orgulje bez pedala sa četiri do pet registara, kakve su česte u malim crkvama ili kapelama. Varaždinski pozitiv izvorno je bio namijenjen svjetovnom muziciranju, za razliku od ostalih spomenutih Rapoldtovih instrumenata čija je namjena bila isključivo crkveno-liturgijska. ${ }^{77}$

Njegova povijest vezana je uz dvorac Borl (Borlin, njem. Ankenstein), koji je smješten u današnjoj općini Cirkulane, ${ }^{78}$ na vrhu brijega na strmoj hridi iznad rijeke Drave. Dvorac se prvi puta spominje 1199., a navodi se i na popisu župa zagrebačke biskupije iz 1334. godine („Item ecclesia sancti Nicolai de Borlin“). ${ }^{79}$ Dvorac je 1639. kupio grof Ivan Karlo Sauer. Sredinom 17. stoljeća je izgorio, zbog čega je u kapeli Presvetog Trojstva kasnije postavljena oltarna pala s prikazom sv. Florijana kako gasi Borl u plamenu. Dvorac su 1674. obnovili supružnici Georg Friedrich Sauer i Ana Barbara Trauttmansdorff, opremivši ga novim inventarom. Tada je nabavljen i pozitiv o kojem je ovdje riječ. U 19. stoljeću dvorac mijenja vlasnike (Poniatowsky, Leslie, Wurmbrand, Kühbeck), a 1922. kupila ga je obitelj Androwsky-Unukić iz Zagreba, u čijem je posjedu ostao do 1936. Tada oporučno prelazi u ruke grofova Bombelles, a potom obitelj Vučetić-Weiss. Tijekom Drugog svjetskog rata okupatori su ga pretvorili u logor, a nakon rata postaje hotel. Nakon što je hotel propao, upravljanje dvorcem preuzela je Republika Slovenija. Danas se ovdje povremeno priređuju kulturna događanja, osobito u ljetnim mjesecima, ali još nije otvoren za javnost.

Kapela u Borlu nije imala kor pa je pozitiv bio smješten s lijeve strane, odmah do ulaza u kapelu iz unutarnjeg dvorišta. Zapis na zračnici „Josef Frankovič Orgelbauer in St. Marein bei Cilli in Bezirk Erlacstein gestimmt 1859 in May und übersetzt herunter in die Kapelle“ (,graditelj orgulja Josef Frankovič iz Šmarja pri Jelšah [njem. St. Marein bei Erlachstein u Donjoj Štajerskoj, nap. V. V.] kod Celja

76 Ladislav ŠABAN, „Rapolt, Rudolf“, Digitalna zbirka Hrvatske akademije znanosti i umjetnosti, http://dizbi.hazu.hr/object/20373. Pristup: 15. svibnja 2018.

77 M. KLEMM, Z. KUŠĆER, n. dj., 8-9.

78 Cirkulane se nalaze u sjeveroistočnoj Sloveniji u pokrajini Štajerskoj i statističkoj regiji Podravskoj. Općina je nastala 2006. izdvajanjem iz općine Gorišnica.

79 L. ŠABAN, „Dva pozitiva u Muzeju grada Varaždina“, 108. 
ugađao u svibnju 1859. i premjestio dolje u kapelu“) upućuje da je pozitiv ranije bio smješten $u$ najvećoj prostoriji $u$ dvorcu, tzv. viteškoj dvorani. Bila je velika točno kao i kapela ispod nje. Prvotno oružarnica, viteška dvorana je tijekom vremena pretvorena u dvoranu za svečanosti i plesove, a oružje je postavljeno kao dekoracija na zidove ili je preseljeno u dvorske hodnike. U Borlu je viteška dvorana služila i kao dvorsko kazalište. Na dnu dvorane po cijeloj širini postavljena je pozornica s oslikanim baroknim portalom. Imala je i oslikani kazališni zastor i na platnu slikane kulise. ${ }^{80}$ Prikazivanje igrokaza, često uz glazbu i pjevanje (Singspiel) bila je omiljena zabava velikaša. Može se pretpostaviti da je i u ovom dvorcu postojao mali komorni sastav koji bi svirao na dvorskim svečanostima, plesovima i u kazališnim predstavama. Naime, u inventaru Franza Antona Sauera, brata Georga Friedricha Sauera, zabilježen je veći broj instrumenata: čembalo, violine, dvije viole da braccio, violone, kontrabas, dva timpana, dvije trube i pet lovačkih rogova. ${ }^{81}$

Po dolasku pozitiva u GMV orguljaru Gradiščaju je 25. rujna 1937. plaćeno 80 dinara za popravak. Najprije je bio smješten na koru dvorske kapelice sv. Lovre u Starom gradu. Na njemu je prvi muzicirao Tomislav Miškulin na Dan muzeja 16. studenog 1937. U muzejskoj dokumentaciji zabilježeno je da je 15. svibnja 1939. kupljen remen za pozitiv u iznosu od 23 dinara. ${ }^{82}$ Na njemu se i u narednom razdoblju povremeno sviralo pri bogoslužju. Restaurirao ga je Ivan Faullend Heferer 1975. što je u ondašnjem Varaždinu i Hrvatskoj predstavljalo pionirski posao. U tjedniku Varaždinske vijesti, u sklopu osvrta na otvorenje 5. Varaždinskih baroknih večeri zabilježeno je: „U renesansnoj sobi u Gradskom muzeju predane su na čuvanje restaurirane barokne orgulje. Uz pozitiv je nastupio Žarko Dropulić, a pjevao bariton Vladimir Ruždjak. ${ }^{\text {83 }}$ Bio je to rezultat zajedničkih napora Krešimira Filića i Ladislava Šabana, u suradnji s Gradskim muzejom Varaždin, Varaždinskim baroknim večerima i Umjetničkom radionicom Heferer koja je izvela restauraciju. ${ }^{84} \mathrm{U}$ renesansnoj dvorani Staroga grada bariton Vladimir Ruždjak, orguljaš Željko Marasović i violinčelist Josip Stojanović snimili su gramofonsku ploču Rana hrvatska glazba uz pozitiv u Varaždinu, koju je 1976. objavio Jugoton.

\footnotetext{
80 Isto , 108.

81 U izvorniku: „Musikalische Instrumenta / 1 Instument, oder flig [flügel] pr $30 \mathrm{fl} / 1$ paar Grosse Paukhen pr $20 \mathrm{fl} / 1$ Violon pr $8 \mathrm{fl} / 1$ Bässetl pr $4 \mathrm{fl} \mathrm{/} 1$ Violin sambt Fuetterall pr $6 \mathrm{fl}$ / Item 2 Violin, und 2 Prätschen so aber ruiniert seydn zusamben pr $6 \mathrm{fl} / 5$ Trompeten pr $12 \mathrm{fl} / 2$ paar Mässingl: und 1 Kupfer; Jägerhorn pr 15 fl.“ Cit. Darja KOTER, n. dj., bilješka 75.

82 Zahvaljujem Jeleni Rančić na ovim podacima.

83 Željko SLUNJSKI (Ž. Sl.), „Počele Barokne večeri“, Varaždinske vijesti, 25. rujna 1975., br. 1600., 8.

84 Dada RUŽA, „Filićev povratak i povratak Filiću“, Radovi Zavoda za znanstveni rad Varaždin, 23, Varaždin, 2012, 204.
} 
Ploča je objavljena u okviru serije Hrvatska glazbena baština. ${ }^{85}$ Nakon obnove pozitiv je - zbog obnove Starog grada - bio smješten u središnjoj dvorani palače Sermage. Od 1989. bio je izložen u stalnom postavu u Baroknoj sobi Staroga grada gdje se na njemu povremeno muziciralo, npr. u okviru Varaždinskih baroknih večeri.

Nova restauracija i djelomična rekonstrukcija povjerena je 2007. Umjetničkoj radionici Heferer, prema prijedlogu obnove pozitiva koji je izradila Orguljaška zaklada don Petar Nakić. Sredstva za obnovu osigurali su Ministarstvo kulture Republike Hrvatske, Grad Varaždin i Varaždinska županija. U postupku restauracije naročita je pozornost posvećena izvornom ustroju instrumenta $i$ težnji da ga se što je višse moguće očuva. Zamijenjeni su svi dijelovi instrumentalnog ustroja koji su bili obnavljani tijekom prijašnjih radova. U obnovi foničkog materijala rekonstruirane su neprimjereno građene svirale (u drvenim i kovinskim registrima), pri čemu su sve obnovljene svirale jednake izvornima. Restauracija drvenih remena za ručno pokretanje mjehova bio je važan doprinos izvornosti instrumenta. Što se tiče temperacije, primijenjena je srednjotonska ugodba $1 \frac{1}{6}$ sintoničke kome koja pridonosi izvornosti zvuka ovog instrumenta. ${ }^{86}$

Restaurirani pozitiv javnosti je predstavljen 16. lipnja 2007. Njegova kolaudacija održana je u sklopu manifestacije Varaždinske muzejske svečanosti, u Baroknoj sobi u Starom gradu. Varaždinski orguljaš Višeslav Jaklin održao je koncert na čijem su programu bile skladbe G. Muffata, J. S. Bacha, G. Ph. Telemanna, J. Pachelbela, D. Buxtehudea, W. A. Mozarta te I. Kaysera. Sljedeći dan, 17. lipnja 2007., u istome prostoru Višeslav Jaklin je održao i drugi koncert na pozitivu, s ponešto izmijenjenim repertoarom. ${ }^{87}$ Objavljena je i knjižica Pozitiv Rudolfa $R a$ poldta u Gradskom muzeju Varaždin: 1668-2007, u kojoj je opisana njegova povijest i restauracija. ${ }^{88}$ Otada se na njemu održavaju koncerti, npr. u okviru festivala Orgulje Heferer i Varaždinskih baroknih večeri, na kojima se izvodi barokna glazba domaćih i stranih skladatelja. Budući da je izložen u stalnom postavu mogu ga razgledati posjetitelji Gradskog muzeja Varaždin. Obnovljeni Rapoldtov pozitiv značajan je doprinos razvoju orguljarske kulture u Varaždinu, ali i doprinos proučavanju orguljarstva u Štajerskoj u 17. stoljeću. Prema tome, uz nacionalno ima i

85 Rana hrvatska glazba uz pozitiv u Varaždinu. Izvode: Vladimir Ruždjak, bariton; Josip Stojanović, violončelo; Željko Marasović, pozitiv. Sadrži skladbe Franje Bosanca, Bartolomea Tromboncina, Vinka Jelića, Julija Skjavetića, Ivana Lukačića, Andrije Motovunjanina, Andrije Patricija i Petra Hektorovića. Jugoton, Zagreb, 1967., LSY-68012.

86 M. KLEMM, Z. KUŠĆER, n. dj., 10-11.

87 Gradski muzej Varaždin: Varaždinske muzejske svečanosti, http://www.gmv.hr/hr/dogadjanja/ varazdinske-muzejske-svecanosti,1189.html?t=d. Pristup: 15. svibnja 2018.

88 Miroslav KLEMM, Zdenko KUŠĆER, Pozitiv Rudolfa Rapoldta u Gradskom muzeju Varaždin 16682007., Gradski muzej Varaždin, Varaždin, 2007. 
međunarodno značenje. Uz Rosenbergerov povijesni klavir, ovaj je pozitiv još jedan uzorni primjer brige, čuvanja i upotrebe glazbenog instrumenta u Gradskom muzeju Varaždin. On nije više samo muzejski izložak nego „„̌ivi instrument s dušom, u čijim će čarobnim i profinjenim zvucima moći uživati novi naraštaji, napose ljubitelja barokne glazbe". ${ }^{.9}$

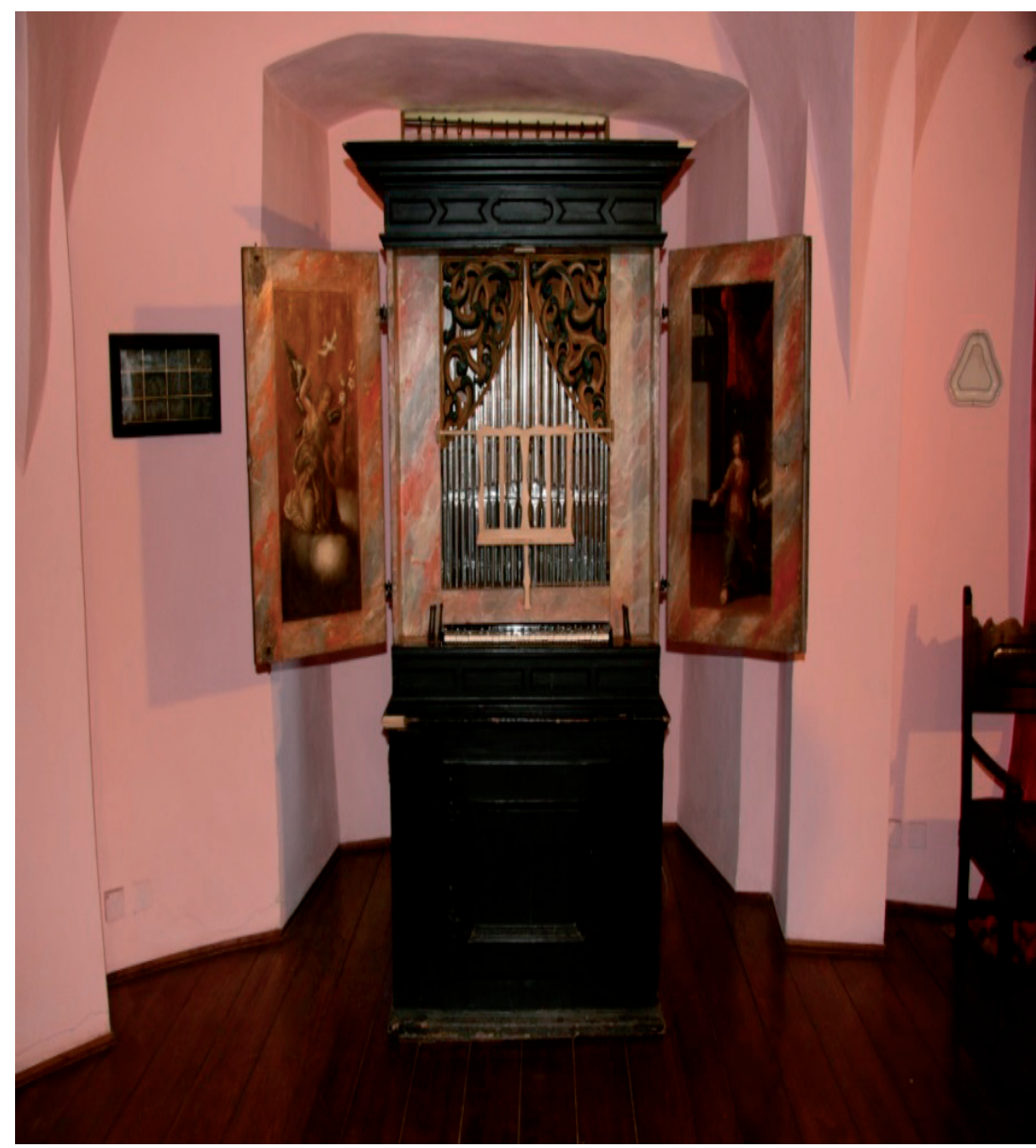

Slika 13. Pozitiv (GMV-KPO 2734), Rudolf Rapoldt, Bruck an der Mur, 1668.

89 M. KLEMM, Z. KUŠĆER, $n . d j ., 2$. 


\section{Pozitiv (GMV-KPO 2618)}

Ovaj pozitiv ranije se nalazio u kapeli sv. Vuka Regensburškog u Vukovoju (općina Klenovnik u Varaždinskoj županiji). Odatle je u teško oštećenom stanju 1964. dospio u Gradski muzej Varaždin. Prema Ladislavu Šabanu, pozitiv iz Vukovoja stariji je od pozitiva iz Borla, ali mu je vremenski raspon nesiguran (1600. - 1650).${ }^{90}$ Kao i pozitiv iz Borla, po vanjštini i strukturi kućišta tipološki pripada renesansno-baroknom ormaru s naglašenim završnim vijencem. Širi je i viši od pozitiva iz Borla. Ukupna visina kućišta iznosi 225,5 cm. Dimenzije donjeg dijela su 87 x 126 × 88 cm; dimenzije gornjeg dijela su $168,5 \times 121$ x $86 \mathrm{~cm} .{ }^{91}$ Vanjština mu je skromnija. Niša je otvorena i nema vrata. U njoj je smješten prospekt sa sviraonikom. Glavni ukras bile su fino izrezbarene zavjese (prvotno zlatne, kasnije prebojane srebrnom bojom) čija ornamentika (guste vitice, cvijet i plod šipka) upućuje na obilježja prve polovice 17. stoljeća. ${ }^{92}$ Donje tipke $(2,2 \times 11,6 \mathrm{~cm})$ su bijele, a gornje $(1,1 \times 7,5 \mathrm{~cm})$ tamnosmeđe boje. Dispozicija registara pokazuje srodnost s onom pozitiva iz Borla. Od pet registara koliko ih je ranije bilo, sa sigurnošću se mogu utvrditi samo tri: Copula maior 8' (velika poklopljenica), Portun 4' (otvorena flauta), Principal 2' (u prospektu). Ostala dva registra možda su Quinta 111/3' i Octav 1'.93 Zračnice su mehaničkog sustava s kliznicama i tonskim kancelama. Vjerojatno ima svirnu trakturu s probodnicama. Duljina klavijature $(63 \mathrm{~cm})$, opseg (od C/E do $c_{3}$ ) i skraćena najdublja oktava odgovaraju karakteristikama pozitiva iz Borla.

Stražnja strana ovog pozitiva bila je zabrtvljena jednostavnim pregradnim poklopcem od tankih dasaka. Na njoj su se nalazila dvoja oslikana krila koja nisu imala funkciju vratiju, nego su samo služila za ukras. Na tim su krilima bili prikazani crkveni učitelji sv. Ambrozije i sv. Augustin, odjeveni u raskošno biskupsko ruho s mitrom i štapom, stojeći na naslikanom kamenom postolju s njihovim imenima. Sv. Ambrozije u ruci drži knjigu, a sv. Augustinu do nogu sjedi dječačić. Oba sveca povezana su s glazbom: sv. Ambrozije bio je reformator liturgijskog pjevanja, a sv. Augustin napisao je traktat De musica. Oštećene slike djelo su prijelaznog razdoblja iz gotike u barok (oko 1600). Bile su naslikane su na dasci i postavljene u dosta široke, s unutarnje strane crveno obojene okvire. Vanjska strana krila bila je obojana svjetlosivom bojom, kao i

90 L. ŠABAN, „Dva pozitiva u Muzeju grada Varaždina“, 105. Usp. i Ladislav ŠABAN, „Varaždin muzej: pozitiv iz sv. Vuka“, Digitalna zbirka Hrvatske akademije znanosti i umjetnosti, http:// dizbi.hazu.hr/object/19961. Pristup: 15. svibnja 2018.

91 Visina $x$ širina $x$ duljina.

92 L. ŠABAN, „Dva pozitiva u Muzeju grada Varaždina“, 110.

93 Isto, 111. 
ostatak kućišta. Okomito, po sredini daske bila su dva uža polja oslikana biljnim ornamentima. ${ }^{94}$

Pozitiv izvorno nije pripadao inventaru kapele sv. Vuka u Vukovoju nego ga je za nju 1807. u Grazu kupio klenovnički župnik Nikola Horvat. U kapelu ga je 7. rujna 1809. postavio Ludwig Gross, orguljar iz Graza. ${ }^{95}$ Gross je vjerojatno prethodno temeljito popravio i obnovio pozitiv. Stavio je novi sviraonik, oblijepio sva propusna mjesta na mjehovima, zračnicama i nekim drvenim sviralama. Može se pretpostaviti da je Horvat pozvao Grossa iz Graza u Klenovnik zato što je od njega kupio taj rabljeni pozitiv pa je ovaj bio obavezan doći. Na stijeni pozitiva pronađen je zapis koji dokazuje da Gross nije bio graditelj pozitiva nego da je instrument znatno stariji. Zapis "Gestimt und Rebarirt Marain 1743 I. L." (,ugodio i popravio [St.] Marain 1743. I. L.“). ${ }^{96}$ Osim nepoznatog orguljara s inicijalima I. L., zapis spominje mjesto $u$ kojem se pozitiv nalazio prije nego je dospio u Graz. U obzir dolazi nekoliko lokacija u Štajerskoj, a ne treba zaboraviti niti na mjesto u Donjoj Štajerskoj spomenuto kod prethodnog pozitiva:

1) Sankt Marein bei Graz - općina u okrugu Graz-Umgebung

2) Sankt Marein im Mürztal - općina u okrugu Bruck an der Mur

3) Sankt Marein bei Knittelfeld - općina u okrugu Murtal

4) Sankt Marein bei Neumarkt - općina i okrugu Murau

5) Šmarje pri Jelšah (njem. St. Marein bei Erlachstein) - općina u Donjoj Štajerskoj.

Nakon popravaka koje je izvršio Gross, kasniji orguljari samo su dodavali zakrpe na zračnicama i drvenim sviralama, ali nisu više ništa obnavljali. Pozitiv u Vukovoju je nakon 1946. teško oštećen i razbijen. O starosti instrumenta nema sigurnih podataka pa je možemo samo pretpostaviti po stilskim obilježjima zavjesa prospekta ili po starosti krilnih slika. Prve upućuju na sredinu 17. stoljeća, a druge dataciju prebacuju na početak stoljeća. Posljednju riječ trebali bi imati restauratori. Ako se pokaže da namaz boje na poleđini krila nije identičan namazu kućišta ili da je kasnije stavljen preko nekog još starijeg namaza, onda su krila dijelovi nekog starijeg oltara i ne pripadaju kućištu. U tom će slučaju starost odrediti zavjese. Ako se pokaže da je boja naličja istovjetna s naličjem kućišta, onda su slike dio iste cjeline čiju dataciju valja odrediti na početak 17. stoljeća. ${ }^{97}$

94 Fotografije orgulja u kapeli sv. Vuka u Vukovju, ornamenata na zavjesama te lika sv. Ambrozija na vratnicama donosi Višnja SEVER-SIGLHUBER, „Orgulje XVII stoljeća u sjeverozapadnoj Hrvatskoj", Peristil: zbornik radova za povijest umjetnosti, 8-9, Zagreb, 1966, 143-147.

95 Na stijeni iznad pozitiva stoji zapis: „1809 den 7 September von Ludwig Gross bürgerl. OrgelBauer in Graz unter dem Hern Nicolaus Hotwath Pfarrer zu Klenovnik“. Usp. L. ŠABAN, „Dva pozitiva u Muzeju grada Varaždina", 112.

96 Isto, 112.

97 Isto, 113. 
Opis instrumenta možemo zahvaliti podacima iz muzeja i još više Ladislavu Šabanu. Od njegova vremena do danas mnogo se toga promijenilo i to nažalost na gore. Zbog zuba vremena, ali i kroz renovaciju prostora i preseljenje čuvaonica GMV-a došlo je do defragmentacije instrumenta. On je danas necjelovit, a sačuvani dijelovi - teško oštećeni - smješteni su u Starom gradu (čuvaonice Marija Terezija i južno krilo) te u Optujskoj ulici (prostori bivše vojarne). U GMV-u se planira objedinjavanje pozitiva, utvrđivanje stanja očuvanosti te $-\mathrm{u}$ idealnom slučaju - restauracija.

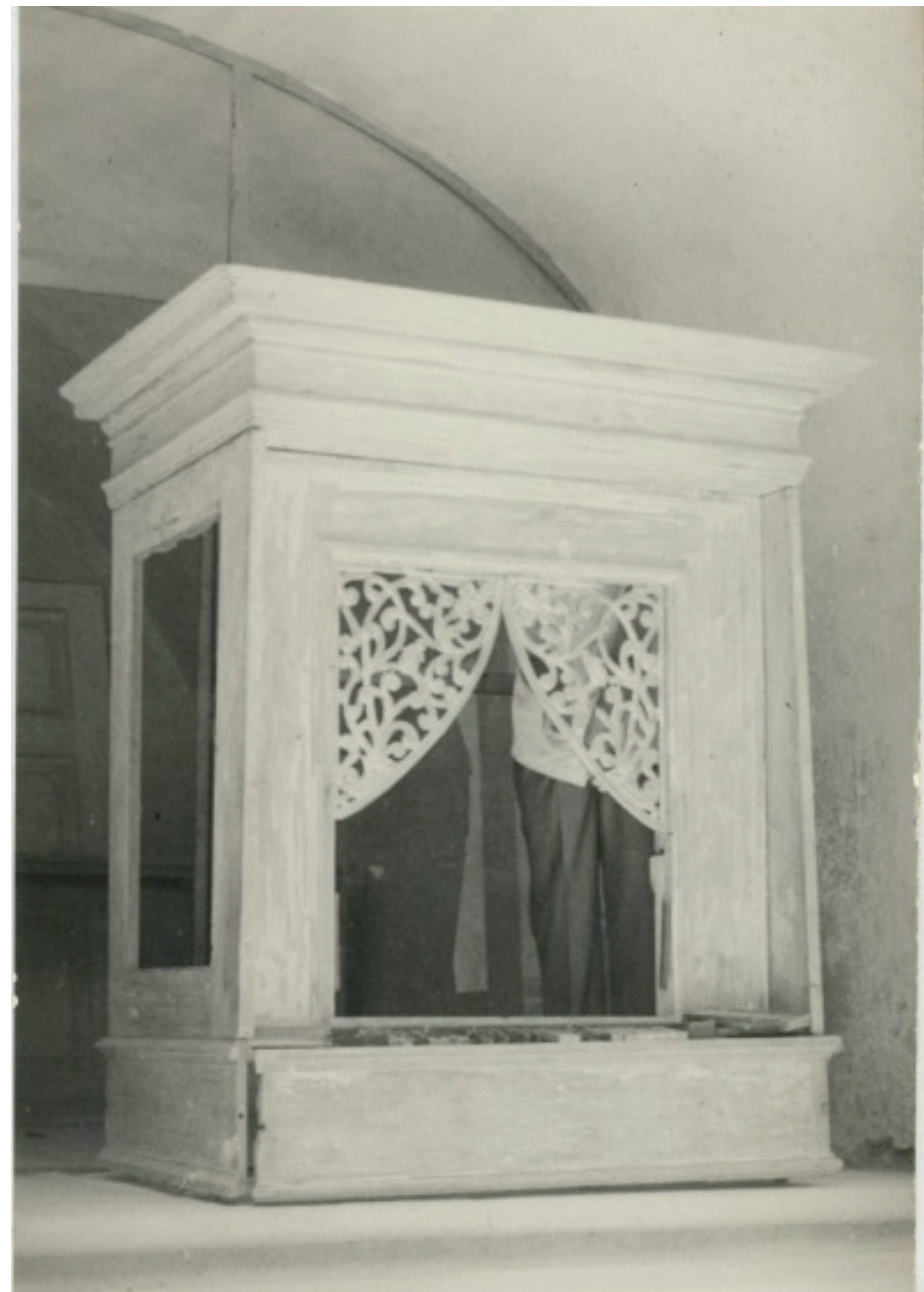

Slika 14. Pozitiv (GMV-KPO 2618), nepoznati graditelj, Štajerska, između 1600. i 1650. 


\section{ZAKLJUČAK}

Skupina instrumenata s tipkama iz fundusa Muzeja grada Varaždina broji ukupno 12 primjeraka: deset klavira - stolni klavir, pet povijesnih klavira iz prve polovice 19. stoljeća, četiri klavira iz druge polovice 19. stoljeća - te dva pozitiva iz 17. stoljeća. Među njihove graditelje ubrajaju se istaknuta imena kao što su Rudolf Rapoldt, Johann Jakesch, Michael Rosenberg, Wilhelm Lange, Carl Schmidt, Carl Kutschera, Josef Kaspar Fritz, Johann Promberger mlađi te Carl i Johann Schweighofer. Grad iz kojeg potječe većina primjeraka je Beč, potvrđujući snažnu pripadnost Varaždina tom kulturnom krugu i utjecajnoj sferi, kao i tamošnju iznimno razvijenu proizvodnju instrumenata s tipkama. Kao glavno administrativno i političko središte Hrvatske u 18. stoljeću, Varaždin nije želio zaostajati za prijestolnicom Habsburške Monarhije. Ona mu je bila uzorom za razvoj kulturnog, a unutar njega i glazbenog života grada. Broj i raznovrsnost sačuvanih instrumenata dokaz je povoljnih materijalnih prilika koje su njihovim vlasnicima omogućavale da ih nabave iz uvaženih inozemnih radionica, njihova dostatnog glazbenog obrazovanja te intenzivnog glazbenog života $u$ „malom Beču“ - kako su suvremenici nazivali Varaždin. Nakon Beča među mjesta njihova podrijetla ubrajaju se Štajerska i Bratislava.

Sakupljanje glazbenih instrumenata u GMV-u svjedoči o razvijenoj svijesti o njihovu značenju te nastojanju da ih se sačuva u što većem broju. Instrumenti s tipkama čuvaju se na različitim mjestima unutar Staroga grada te u palačama Sermage i Herzer. U sklopu reorganizacije čuvaonica u planu je pohrana svih klavira u jednu čuvaonicu poluotvorenog tipa koja bi služila kao studijski depo. Na taj bi način građa bila dostupna za javnost, podjednako posjetiteljima i istraživačima. Time bi se otvorila mogućnost da se dvama restauriranim instrumentima - pozitivu Rudolfa Rapoldta i povijesnom klaviru Michaela Rosenbergera - pridruže još neki primjerci iz ove skupine kao što su stolni klavir Johanna Jakescha i povijesni klavir nepoznatog graditelja (GMV-KPO 63436) koji je bio u vlasništvu bana Josipa Jelačića (za oba instrumenta su načinjeni prijedlozi obnove te su otpremljeni na restauraciju), ili povijesni klaviri Wilhelma Langea i Karla Schmidta (teško oštećeni i necjeloviti). Dugoročno, to bi bio poticaj da oštećenih i necjelovitih instrumenata bude manje, a obnovljenih i onih u postupku obnove više.

Ovi instrumenti su kulturni simboli Varaždina, određenog vremena, pojedinca (vlasnika) i/ili skupine. U njima su sačuvane različite značajke: kulturne, povijesne, društvene, estetske, tehničke, akustičke i dr. Istraživače, restauratore, institucije, ali i širu zajednicu obvezuju stoga da im sustavnom brigom u sadašnjosti osiguraju odgovarajuće mjesto u budućnosti. 


\section{LITERATURA}

1. Bericht über die zweite allgemeine österreichische Gewerbsprodukten-Ausstellung im Jahre 1839, K. K. Hof- und Staats-Aerarial Druckerei, Beč, 1840.

2. "Domaće vijesti“, Narodno jedinstvo, 6. siječnja 1923., br. 1., str. 4.

3. "Domaće vijesti“, Narodno jedinstvo, 10. lipnja 1926., br. 22., str. 2.

4. „Hrvatskim epigonima 1923.", Narodno jedinstvo, 6. siječnja 1926., br. 1., str. $1-2$.

5. Katalog der Allgemeinen deutschen Industrie-Ausstellung zu München im Jahre 1854, Gemeinschaftlich gedruckt von G. Franz-W. Pössenvacher, München, 1854.

6. Vjekoslav BABUKIĆ, „Rodoljubi slavjanski svomu obćeljubljenomu Josipu Jelačiću dalmatinsko-harvatsko-slavonskomu Banu“, Danica horvatska, slavonska i dalmatinska, 11. studenog 1848., br. 46., str. 1-2.

7. Marija BARIĆ, „Iz biografije Jagode Kralj Novak, nacionalne prvakinje HNK u Varaždinu“, Varaždinske vijesti, 8. svibnja 2015., http://arhiva.varazdinskevijesti.hr/kultura/iz-biografije-jagode-kralj-novak-nacionalne-prvakinje-hnku-varazdinu.html. Pristup: 15. svibnja 2018.

8. Marija BARIĆ, „Klavir iz obitelji prof. Franje Košćeca doniran GMV-u“, Varaždinske vijesti, 24. ožujka 2015., http://arhiva.varazdinske-vijesti.hr/kultura/ klavir-iz-obitelji-prof-franje-kosceca-doniran-gmv-u.html. Pristup: 15. svibnja 2018.

9. Antica BREGOVIĆ, „Franjo Košćec: osnivač Entomološkog odjela Gradskog muzeja Varaždin", Muzejski vjesnik: glasilo muzeja sjeverozapadne Hrvatske, 4, Varaždin, 1982, 77-79.

10. Lovorka ČORALIĆ, „Hrvatska banica - Sofija Stockau Jelačić (1834.-1877.)“, Godišnjak Njemačke narodnosne zajednice - VDG Jahrbuch, 3, Osijek, 1997, 97 106.

11. Giovanni Paolo DI STEFANO, Selima Giorgia GIULIANO, Sandra PROTO, ur., Strumenti musicali in Sicilia, CRicd Regione Siciliana, Palermo, 2013.

12. Christian FASTL, "Schweighofer, Familie“, Oesterreichisches Musiklexikon Online, http://www.musiklexikon.ac.at/ml/musik_S/Schweighofer_Familie.xml. Pristup: 15. svibnja 2018.

13. Krešimir FILIĆ, Glazbeni život Varaždina, Muzička škola Varaždin, Varaždin, 1972.

14. Krešimir FILIĆ, „Muzička zbirka u Padovčevoj kući?“, Vjesnik-varaždinsko izdanje, 19. veljače 1968., br. 7544., str. 11.

15. Krešimir FILIĆ, „Naš varaždinski muzej”, Varaždinske novosti, 24. prosinca 1929., br. 3., str. 8 . 
16. Ljubomir GAŠPAROVIĆ, Deset klavira iz zbirke Ljubomira Gašparovića, Muzej za umjetnost i obrt, Zagreb, 2012.

17. Uwe HARTEN, „Promberger, Familie“, Oesterreichisches Musiklexikon Online, http://www.musiklexikon.ac.at/ml/musik_P/Promberger_Familie.xml. Pristup: 15. svibnja 2018.

18. Rudolf HOPFNER, „Jakesch (Jakisch, Jaksch), Familie“, Oesterreichisches Musiklexikon Online, http://www.musiklexikon.ac.at/ml/musik_J/Jakesch_Familie.xml. Pristup: 15. svibnja 2018.

19. Miroslav KLEMM, Zdenko KUŠĆER, Pozitiv Rudolfa Rapoldta u Gradskom muzeju Varaždin 1668-2007., Gradski muzej Varaždin, Varaždin, 2007.

20. Darja KOTER, Glasbilarstvo na Slovenskem, Založba Obzorja, Maribor, 2001.

21. Zdenko KUŠĆER, "Zbirka Hammerklavira u Gradskom muzeju Varaždin“, St. Gallen-Varaždin, 2007., studija iz dokumentacije Gradskog muzeja Varaždin (rukopis).

22. Michael LATCHAM, "Rosenberger", Oxford Music Online. Grove Music Online, http://www.oxfordmusiconline.com/grovemusic/view/10.1093/ gmo/9781561592630.001.0001/omo-9781561592630-e-4002291433. Pristup: 15. svibnja 2018.

23. Michael LATCHAM, The Stringing, Scaling and Pitch of Hammerflügel built in the Southern German and Viennese traditions 1780-1820, Musikverlag Katzbichler, München - Salzburg, 2000.

24. Martin LUKAVEČKI, „Cerska lipa - svjedok povijesnog događaja“, 30 dana, 25. ožujka 2016., br. 18., str. 38-41.

25. Richard MAUNDER, Keyboard Instruments in Eighteenth-Century Vienna, Clarendon Press, Oxford, 1998.

26. Martha NOVAK CLINKSCALE, Makers of the Piano 1820-1860, Oxford University Press, New York, 1999., sv. 2.

27. Hubert PETTAN, Popis skladbi Ivana Zajca, Jugoslavenska akademija znanosti i umjetnosti, Zagreb, 1956.

28. Bosiljka PERIĆ KEMPF, Povijesni klavir Hammerflügel: Michael Rosenberger: Bürger in Wien, Gradski muzej Varaždin-Atelier Heferer, Varaždin, 2010.

29. Alexander RAUSCH, "Schmidt, Carl Wilhelm“, Oesterreichisches Musiklexikon Online, http://www.musiklexikon.ac.at/ml/musik_S/Schmidt_Carl.xml. Pristup: 15. svibnja 2018.

30. Dada RUŽA, „Filićev povratak i povratak Filiću“, Radovi Zavoda za znanstveni rad Varaždin, 23, Varaždin, 2012, 199-208. 
31. Howard SCHOTT, Anne BEETEM ACKER, "Schweighofer", Oxford Music Online. Grove Music Online, http://www.oxfordmusiconline.com/grovemusic/ view/10.1093/gmo/9781561592630.001.0001/omo-9781561592630-e-4002294747. Pristup: 15. svibnja 2018.

32. Višnja SEVER-SIGLHUBER, „Orgulje XVII stoljeća u sjeverozapadnoj Hrvatskoj“" Peristil: zbornik radova za povijest umjetnosti, 8-9, Zagreb, 1966.

33. Željko SLUNJSKI (Ž. Sl.), „Počele Barokne večeri“, Varaždinske vijesti, 25. rujna 1975., br. 1600., 8 .

34. Nikša STANČIĆ, „Jelačić, Josip“, Hrvatski biografski leksikon, ur. Trpimir MACAN, Leksikografski zavod Miroslava Krleže, Zagreb, 2005., sv. 6, 394-401.

35. Ladislav ŠABAN, „Dva pozitiva u Muzeju grada Varaždina“, Godišnjak Gradskog muzeja Varaždin, 4, Varaždin, 1970, 105-114.

36. Ladislav ŠABAN, 150 godina Hrvatskog glazbenog zavoda, Hrvatski glazbeni zavod, Zagreb, 1982.

37. Vlasta ŠVOGER, „Ban Josip Jelačić u očima svojih suvremenika“, Zbornik Odsjeka za povijesne znanosti Zavoda za povijesne i društvene znanosti Hrvatske akademije znanosti i umjetnosti, 31, Zagreb, 2013, 248-294.

38. Lovro ŽUPANOVIĆ, Vatroslav Lisinski (1819-1854): život, djelo, značenje, Jugoslavenska akademija znanosti i umjetnosti, Zagreb, 1969.

\section{INTERNETSKE STRANICE}

1. Clinkscale Online: A Comprehensive Database of Early Pianos, 1700-1860, http://earlypianos.org/. Pristup: 15 svibnja 2018.

2. Digitalna zbirka Hrvatske akademije znanosti i umjetnosti - Ostavština Ladislava Šabana - Građa o orguljama: lokaliteti \& Građa o orguljama: graditelji, http://dizbi.hazu.hr. Pristup: 15. svibnja 2018.

3. Edwin Beunk Collection, http://www.fortepiano.nl. Pristup: 15. svibnja 2018.

4. Facteurs de pianos à Vienne, http://www.lieveverbeeck.eu/Pianos_viennois. htm. Pristup: 15. svibnja 2018.

5. Finchcocks Musical Museum, http://www.finchcocks.co.uk. Pristup: 15. svibnja 2018.

6. Centre International du Pianoforte Ad Libitum, http://www.pianoforteadlibitum.org. Pristup: 15. svibnja 2018.

7. Gradski muzej Varaždin, http://www.gmv.hr. Pristup: 15. svibnja 2018.

8. Hrvatsko narodno kazalište u Varaždinu, http://www.hnkvz.hr. Pristup: 15. svibnja 2018.

9. Scenkonstmuseet, http://instrument.musikverket.se. Pristup: 15. svibnja 2018. 


\section{SAŽETAK \\ INSTRUMENTI S TIPKAMA IZ FUNDUSA GRADSKOG MUZEJA VARAŽDIN}

Skupina instrumenata s tipkama iz fundusa Muzeja grada Varaždina broji ukupno 12 primjeraka: deset klavira - stolni klavir nastao između 1790. i 1810., pet povijesnih klavira iz prve polovice 19. stoljeća, četiri klavira iz druge polovice 19. stoljeća - te dva pozitiva iz 17. stoljeća. Među njihove graditelje ubrajaju se istaknuta imena kao što su Rudolf Rapoldt, Johann Jakesch, Michael Rosenberg, Wilhelm Lange, Carl Schmidt, Carl Kutschera, Josef Kaspar Fritz, Johann Promberger mlađi te Carl i Johann Schweighofer. Grad iz kojeg potječe većina instrumenata je Beč, potvrđujući snažnu pripadnost Varaždina tom kulturnom krugu i utjecajnoj sferi, a slijede Štajerska i Bratislava. Broj i raznovrsnost instrumenata s tipkama u GMV-u dokaz su povoljnih materijalnih prilika koje su njihovim vlasnicima omogućavale da ih nabave iz uvaženih inozemnih radionica, njihova dostatnog glazbenog obrazovanja te intenzivnog glazbenog života $u$ „malom Beču“ (kako su suvremenici nazivali Varaždin). Sakupljanje u GMV-u svjedoči o razvijenoj svijesti o njihovu značenju te nastojanju da ih se sačuva u što većem broju. Pohrana u muzej spasila je neke od instrumenata - važne dijelove kulturne baštine - od nestajanja, a nekima je omogućila i prijeko potrebnu restauraciju. Među restaurirane instrumente ubrajaju se pozitiv Rudolfa Rapoldta i povijesni klavir Michaela Rosenbergera, a u postupku restauracije su stolni klavir Johanna Jakescha te povijesni klavir nepoznatog graditelja koji je bio u vlasništvu bana Josipa Jelačića.

Ključne riječi: Varaždin; Gradski muzej Varaždin; instrumenti s tipkama; klavir; pozitiv; kulturna baština; restauracija. 


\section{SUMMARY \\ KEYBOARD INSTRUMENTS FROM THE HOLDINGS OF THE VARAŽDIN CITY MUSEUM}

A group of keyboard instruments from the holdings of the Varaždin City Museum consists of 12 objects: ten pianos - the square piano built between 1790 and 1810, five historic pianos from the first half of the 19th century, four pianos from the second half of the 19th century - as well as two positive organs from the 17th century. They were built by the prominent instrument makers such as Rudolf Rapoldt, Johann Jakesch, Michael Rosenberg, Wilhelm Lange, Carl Schmidt, Carl Kutschera, Josef Kaspar Fritz, Johann Promberger younger, and brothers Carl and Johann Schweighofer. Most of the instruments originate from Vienna, which confirms its cultural influence on Varaždin; Styria and Bratislava follow. The number and variety of the keyboard instruments kept in the Varaždin City Museum is evidence of a favourable economical situation of their past owners that allowed them them to purchase these keyboard intruments from reputable international workshops, their adequate music education, as well as intensive music life in "the little Vienna" (as contemporaries used to call Varaždin). Instruments collecting in the City Musem of Varaždin is a testimony to a developed awareness of their significance and an effort to saving them as many of them as possible. Being stored in the museums saved many of them - important parts of the cultural heritage - from disappearing. Furthermore, for some of them indispensable restoration was provided. Rudolf Rapoldt's positive organ and Michael Rosenberger's historic piano were restored, while Johann Jakesch's square piano and historic piano by an unknown builder, earlier owned by the Ban of Croatia Josip Jelačić, are in the process of being restored.

Key Words: Varaždin; Varaždin City Museum; keyboard instruments; piano; positive organ; cultural heritage; restoration. 
Vilena Vrbanić: Instrumenti s tipkama iz fundusa Gradskog muzeja Varaždin

Radovi Zavoda za znanstveni rad HAZU Varaždin; br. 29, 2018, str. 129-177

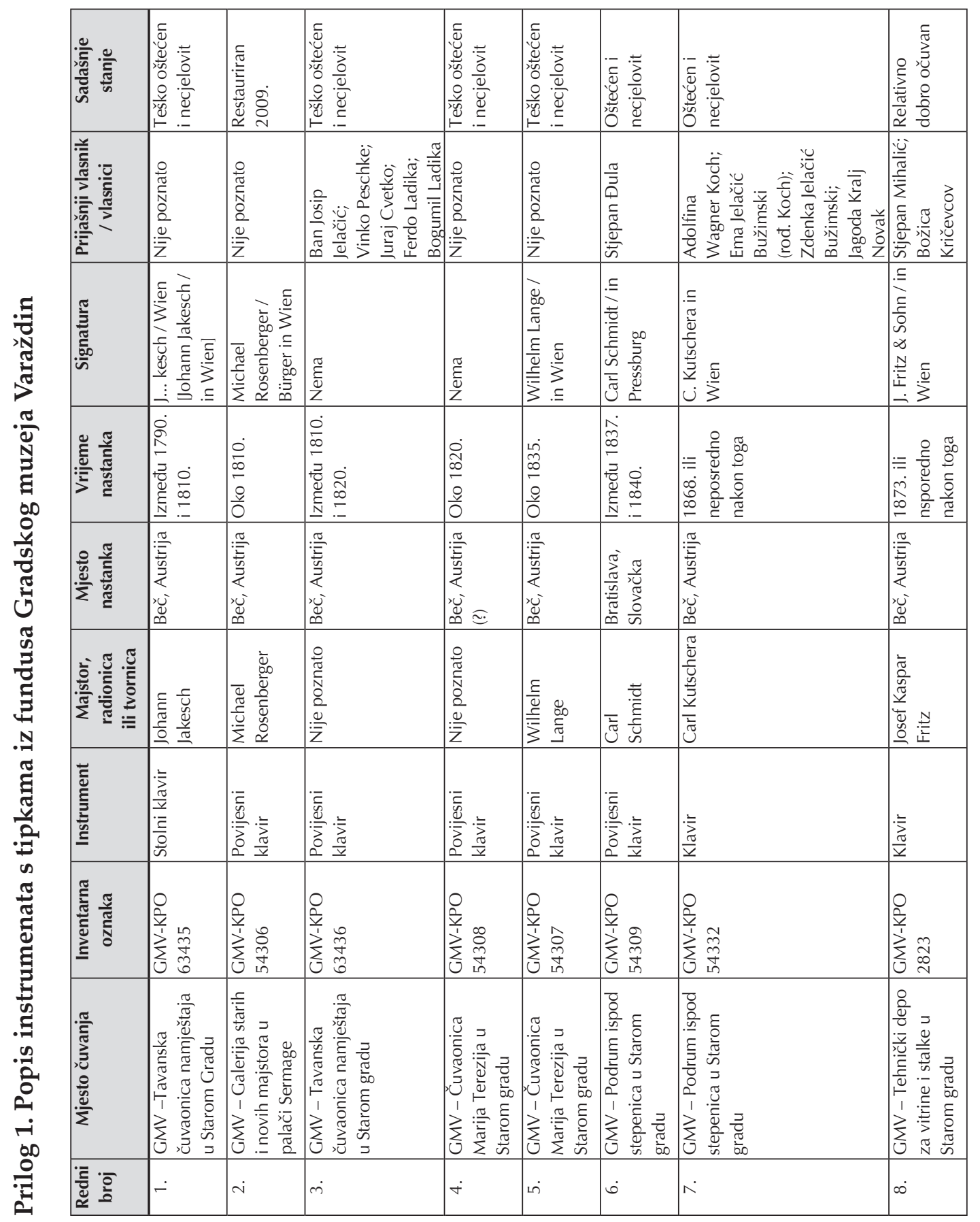


Vilena Vrbanić: Instrumenti s tipkama iz fundusa Gradskog muzeja Varaždin

Radovi Zavoda za znanstveni rad HAZU Varaždin; br. 29, 2018., str. 129-177

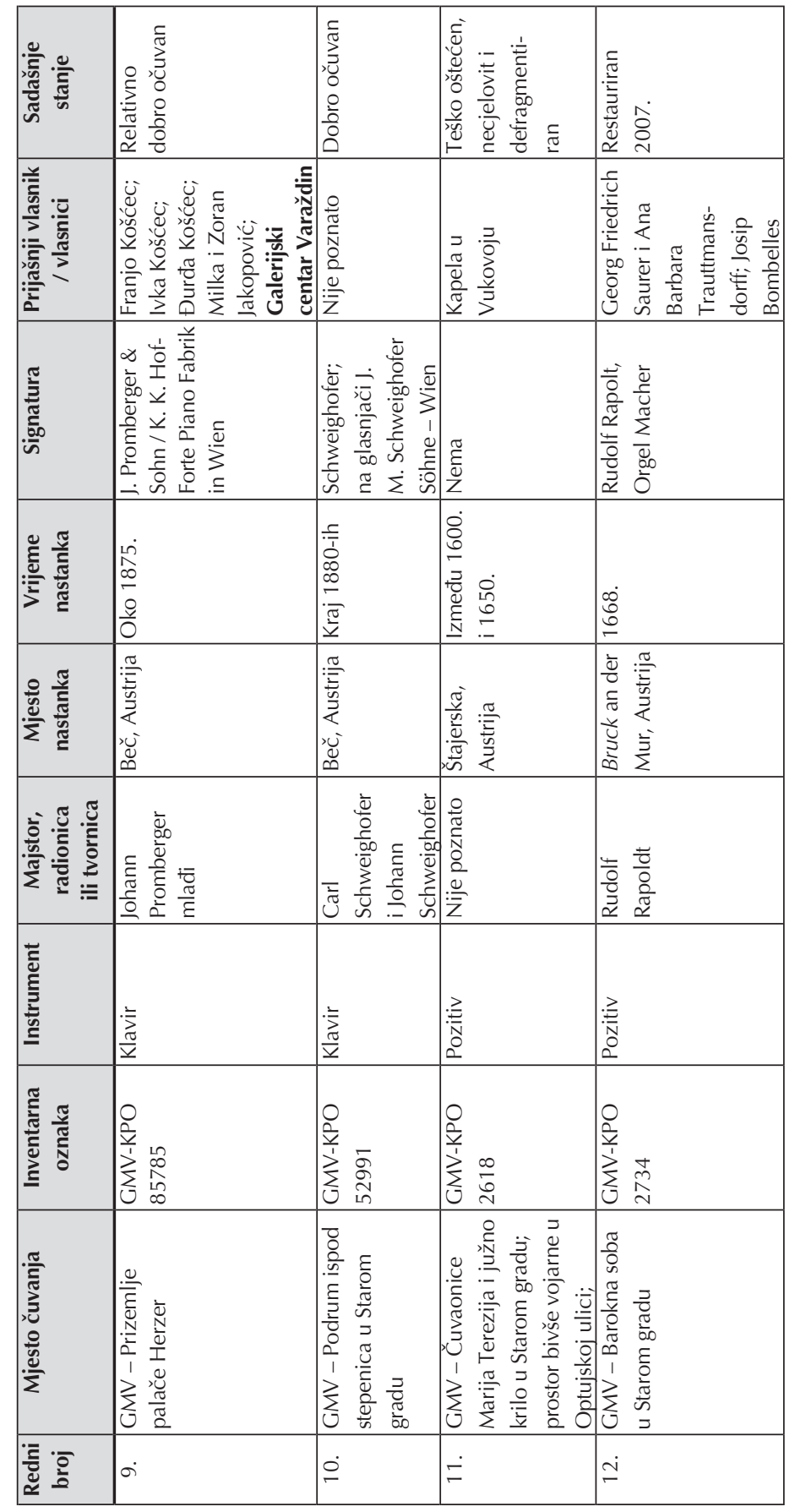

